OPEN ACCESS

Edited by:

Raghuram Kandimalla, James Graham Brown Cancer Center,

United States

Reviewed by:

Saif Khan,

University of Ha'il, Saudi Arabia

Suman Kumar Samanta,

Ministry of Science and Technology,

India

${ }^{*}$ Correspondence:

Anupam Bishayee

abishayee@lecom.edu;

abishayee@gmail.com

Arijit Mondal

juarijitmonda/@gmail.com

Specialty section:

This article was submitted to Pharmacology of Anti-Cancer Drugs,

a section of the journal

Frontiers in Oncology

Received: 19 April 2021

Accepted: 24 May 2021

Published: 07 July 2021

Citation:

Mondal A, Banerjee S, Bose S, Das PP, Sandberg EN, Atanasov AG

and Bishayee $A$ (2021) Cancer

Preventive and Therapeutic

Potential of Banana and its

Bioactive Constituents: A

Systematic, Comprehensive,

and Mechanistic Review.

Front. Oncol. 11:697143.

doi: 10.3389/fonc.2021.697143

\section{Cancer Preventive and Therapeutic Potential of Banana and Its Bioactive Constituents: A Systematic, Comprehensive, and Mechanistic Review}

\author{
Arijit Mondal $^{1 *}$, Sabyasachi Banerjee ${ }^{2}$, Sankhadip Bose ${ }^{3}$, Partha Pratim Das ${ }^{3}$, \\ Elise N. Sandberg ${ }^{4}$, Atanas G. Atanasov ${ }^{5,6,7}$ and Anupam Bishayee ${ }^{4 *}$ \\ ${ }^{1}$ Department of Pharmaceutical Chemistry, Bengal College of Pharmaceutical Technology, Dubrajpur, India, ${ }^{2}$ Department of \\ Pharmaceutical Chemistry, Gupta College of Technological Sciences, Asansol, India, ${ }^{3}$ Department of Pharmacognosy, \\ Bengal School of Technology, Chuchura, India, ${ }^{4}$ Lake Erie College of Osteopathic Medicine, Bradenton, FL, United States, \\ ${ }^{5}$ Ludwig Boltzmann Institute for Digital Health and Patient Safety, Medical University of Vienna, Vienna, Austria, ${ }^{6}$ Institute of \\ Genetics and Animal Biotechnology of the Polish Academy of Sciences, Magdalenka, Poland, ${ }^{7}$ Department of \\ Pharmacognosy, University of Vienna, Vienna, Austria
}

Background: The banana (Musa spp.) plant produces elongated and edible fruit. The two main parthenocarpic species of banana are Musa accuminata Colla and Musa balbisiana Colla. There are several health-promoting and disease-preventing effects of Musa accuminata Colla, which are attributed to its important bioactive compounds, including phenolics, carotenoids, biogenic amines, phytosterols, and volatile oils, found in the stem, fruit, pseudostem, leaf, flower, sap, inner trunk, root, and inner core. Banana possesses numerous pharmacological activities, such as antioxidant, immunomodulatory, antimicrobial, antiulcerogenic, hypolipidemic, hypoglycemic, leishmanicidal, anthelmintic, and anticancer properties. Various individual studies have reported anticancer effects of different components of the banana plant. However, according to our understanding, an up-to-date, systematic, and critical analysis of existing scientific results has not yet been carried out.

Objectives: This review aims to include a thorough assessment of banana and its phytochemicals for cancer prevention and therapy with a focus on cellular and molecular mechanisms of action.

Methods: The available research studies on anticancer activities of banana extracts, fractions and pure compounds were collected using various scholarly databases, such as PubMed, ScienceDirect, and Scopus, based on predetermined selection criteria.

Results: Various banana extracts, fractions, and phytoconstituents, including ferulic acid, protocatechualdehyde, 2-pentanone, 4-epicyclomusalenone, cycloeucalenol acetate, and chlorogenic acid, have been shown to exhibit cancer preventative and anticancer activities in breast, cervical, colorectal, esophageal, hepatic, oral, prostate, and skin cancers. Bioactive components present in bananas have exhibited antiproliferative, cell 
cycle arrest-inducing, apoptotic, anti-adhesive, anti-invasive, and antiangiogenic effects through modulation of diverse, dysregulated oncogenic signaling pathways.

Conclusion: Based on the critical analysis of available literature, banana products and phytoconstituents show enormous potential for future development of drugs for cancer prevention and therapy. However, more mechanistic studies and well-designed clinical trials should be performed to establish its efficacy.

Keywords: cancer, banana, Musa accuminata Colla, Musa balbisiana Colla, Musa spp., prevention, therapy, molecular mechanisms

\section{INTRODUCTION}

Cancer, the second most frequent cause of mortality, is a hyperproliferative disorder that involves cellular transformation, deregulation of apoptosis, and excessive proliferation, invasion, angiogenesis, and metastasis (1). Despite innovative therapeutic approaches and newer technological developments, cancer continues to be amongst the most fatal disorders (2, 3). According to the 2020 Global Cancer Observatory report provided by the International Agency for Research on Cancer (World Health Organization), there were 18.1 million new cases of cancer and 9.5 million cancer-related deaths that occurred globally in 2018. They also stated that the number of newly diagnosed cancer cases is projected to increase to 29.5 million per year, and projected cancerrelated deaths are expected to increase to16.4 million per year by 2040 (www.cancer.gov). While the precise cause for cancer initiation is still unclear, the most important contributing variables for this condition are toxins, pollution, radioactive substances, oncogenic viruses $(4,5)$, and epigenetic abnormalities (6). Many anticancer medications currently in use not only destroy cancer cells, but also healthy cells too. The major obstacles involved with cancer chemotherapy are non-specific targeting and the evolution of drug resistance. The need for more effective anticancer medications with improved safety profiles has become an urgent need to defeat this dreaded disease, despite significant advances in cancer screening, diagnosis, and treatment.

For most of the world, modern medicine has replaced traditional medicine as means of therapy for human illnesses (7). Nevertheless, the use of medicinal plants for health promotion and disease prevention has increased in recent decades (8). Phytochemicals are being extensively investigated, and they have demonstrated promising anticarcinogenic properties by interfering with cancer initiation and modulating various pathways, including cell proliferation, differentiation, apoptosis, angiogenesis, invasion, and metastasis (9-12).

The term "banana" refers to the cultivated varieties of the genus $M u s a$, which are made up of two subgroups: sweet bananas and plantains (13). Musa, Ensete, and Musella are the three genera of the Musaceae family (14), with the Musa genus comprising of 65 species of wild and cultivated bananas and plantains. Banana has been described in ancient Indian treatises, including the Ramayana (2000 BC), Arthsastra (250 BC), and Chilappthikaram (500 AD), suggesting the fruit's importance and demonstrating its ancient use in India. The genus name
Musa was chosen to commemorate Roman physician and botanist Antonius Musa (63 BC-14 AD) (15). Historically, Musa acuminata has been discovered in the native habitats of India (15). At present, banana is cultivated around the world, and the significant producers of banana fruits are India (29 million tonnes/year), China (11 million tonnes/year), Philippines (7.5 million tonnes/year), and Brazil, as well as Ecuador, which produces 7 million tonnes/year on average (16).

The banana is a perennial herb that looks like a tree (Figure 1A). It forms shoots that emerge from the rhizome's lateral buds, which then grow into fruit-bearing stems. A pseudostem (Figure 1B) begins to appear like a trunk, however it is actually is a compact assembly of wrapping, spirally arranged leaf sheaths. The banana plant's flowers (Figure 1C) produce a big spike, which subsequently opens by turning downward towards the soil. A single plant produces both male and female flowers. The fruits (Figure 1D) are green or yellow in color, have a long shape, and are produced in bunches and clusters. Each leaf (Figure 1E) arises from the pseudostem's center. The elongating leaf sheath's distal end expands into a petiole. The midrib, which splits the blade into two lamina halves, is formed by the petiole (17).

Nearly every portion of the banana plant has its essential use and is beneficial in many respects to mankind. Traditionally, $M$. acuminate plants have been used to treat non-communicable as well as transmissible diseases, especially in Asia and Africa. It has been extensively used by indigenous people as both food and medicine $(18,19)$. Various parts of the plant, such as the stem, fruit, pseudostem, leaf, vine, sap, inner trunk, root, and inner core, have been used in the management of various diseases, including the regulation of blood pressure (20), diabetes (18), hypertension (21), anemia (22), allergic reaction, microbial infections, and chronic bronchitis disorders. M. acuminate has also been used for the treatment of fever, cough, tuberculosis, and dysentery by many tribes and communities $(23,24)$. The root extract has been utilized to prevent conception (25), stimulate labor (26), and cure infections of sexually transmitted diseases, such as human immunodeficiency virus-related infections, internal and external sores of the genitalia, vaginitis and leucorrhoea $(27,28)$. Some common uses recorded in the literature include its usefulness as an anthelmintic, as dressing for cuts and blistered skin, and as a liqueur to reduce joint inflammation and promote blood circulation (15). Aside from the conventional uses mentioned earlier, the Musa species has 

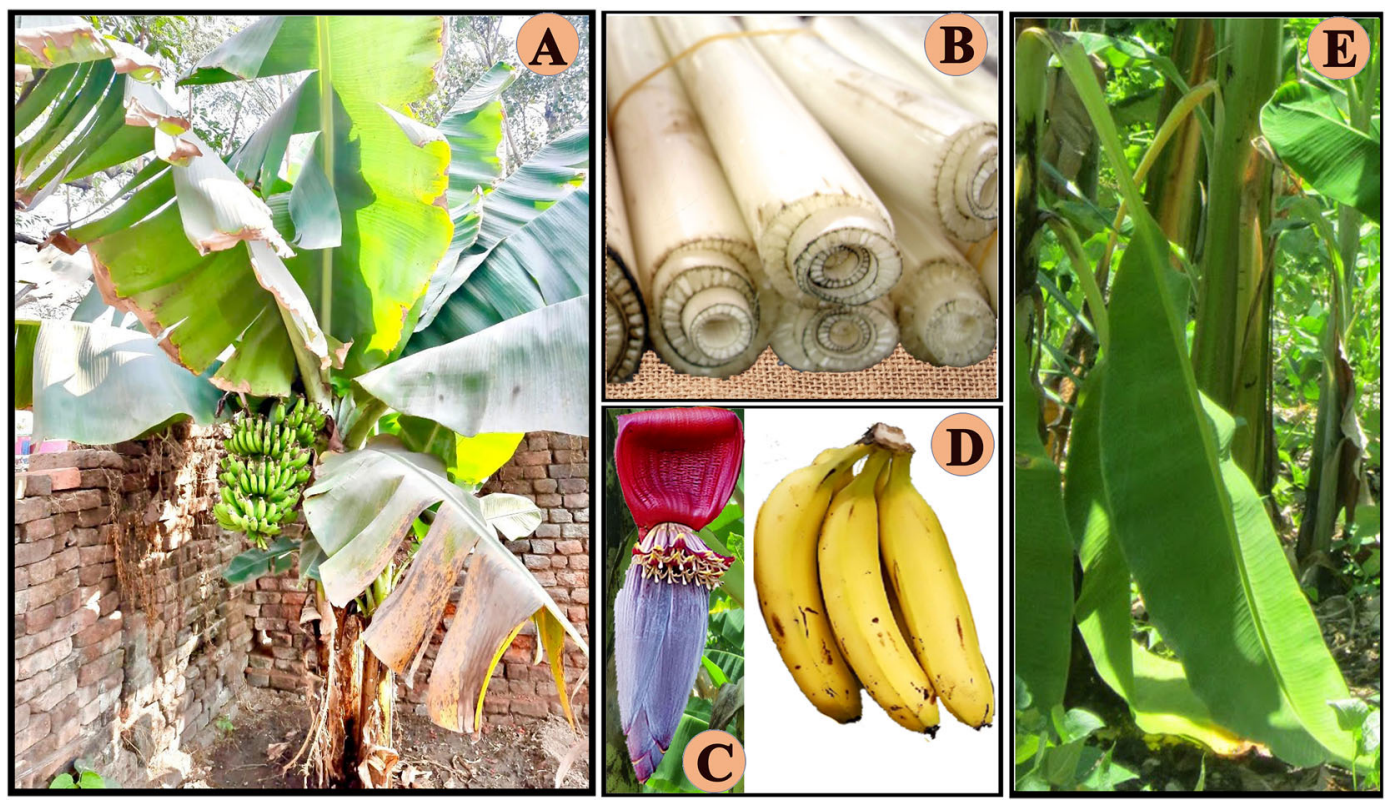

FIGURE 1 | Various photographs of banana showing a whole plant (A), pseudostem (B), flowers (C), fruits (D) and leaves (E).

also been documented to possess pharmacological activities, demonstrating antioxidant, immunomodulatory, antimicrobial, anticancer, antiulcerogenic, hypolipidemic, hypoglycemic, leishmanicidal, and anthelmintic properties (29).

Many bioactive phytoconstituents of bananas have been isolated, characterized, and analyzed for their anticancer properties; however, no previous reviews offer a systematic analysis of published anticancer studies of Musa species. There are only a limited number of prior publications that provide a brief overview of the nutritional values of banana and its overall pharmacological activities $(29,30)$. There are no articles focusing on the antineoplastic properties of Musa species, their phytoconstituents in different kind of cancers and related signaling pathways. While there are numerous and emerging information on anticancer properties of banana and its constituents based on laboratory and clinical findings, a comprehensive assessment of cancer preventive and therapeutic characteristics of banana, banana products, extracts, fractions, and isolated phytochemicals has yet to be performed. In view of this limitation, our current work elucidates cancer preventive and therapeutic potential of banana and its bioactive phytoconstituents observed in several types of cancers and highlights underlying mechanisms of action, which involve targeting various cell signaling pathways and molecules.

\section{PHYTOCHEMICAL PROFILES OF MUSA SPECIES}

The phytochemical analysis of different anatomical parts of banana plant, such as the leaves, fruits, peels, flowers, pseudostems, and rhizomes, has shown that there are numerous secondary plant metabolites, including polyphenols, terpenoids, alkaloids, steroids, anthocyanins, tannins, and fatty acids (Table 1). Banana fruit has been recorded as a significant source of phenolic compounds, including phenolic acids, flavonoids, and glycosides. The pulps and peels of banana and plantain have demonstrated potential to be utilized by the pharmaceutical and food industries for their catechin and rutin content $(60,61)$. Plantain pulps and peels are also a good resource of phenolic compounds. Recent examinations of plantains have revealed that hydroxycinnamic acids represent the majority of phenolic compounds in the fruit pulp, while flavonoids are mostly found in higher concentrations in the peel (62).

Borges et al. (60) proposed that parental combinations of banana genotypes of $M$. acuminata and M. balbisiana may be chosen for hybrid production. The biofortification of Musa spp. produced diploid, triploid, and tetraploid hybrids which contained higher amounts of bioactive compounds than non-hybrid plants. Several studies have reported catechin, epicatechin, and gallocatechin as major compounds in the triploids cultivars Highgate (AAA) genotype of $M$. acuminata and $M$. balbisiana which have an epicatechin content of $114.44 \mathrm{mg} / 100 \mathrm{~g}$ dry weight basis and gallocatechin content of $591.41 \mathrm{mg} / 100 \mathrm{~g}$ dry weight basis. In addition to catechin compounds, protocatechuic acid, gallic acid, 7-O-neohesperoside naringenin, and hydroxycinnamic acids have additionally been identified in banana pulp (41, 60, 62, 63).

The content of phenolic compounds varies in the raw and ripe fruits. Thermal treatments of the banana fruits weakened the cell wall and facilitated the release of phenolic component, 
TABLE 1 | Phytochemicals identified in various parts of Musa spp.

\begin{tabular}{|c|c|c|c|c|c|}
\hline Plant parts & Category & Phytochemicals from various banana cultivars & Quantitative values & Extract & References \\
\hline \multirow[t]{5}{*}{ Ripe fruit } & Phenolic acids & Octadeca-9,12,15 trienoic acid (1) & $36-405 \mathrm{mg} / \mathrm{kg}$ of dry material & Dichloromethane & (31) \\
\hline & & Octadeca-9,12-dienoicacid (2) & $12-198 \mathrm{mg} / \mathrm{kg}$ of dry material & & \\
\hline & & Vanillic acid (3) & $8.54 \mathrm{mg} / 100 \mathrm{~g}$ of acetone extract & Acetone & (32) \\
\hline & & Caffeic acid (4) & $1.36 \mathrm{mg} / 100 \mathrm{~g}$ of acetone extract & & \\
\hline & & Ellagic acid (5) & $68.82 \mathrm{mg} / 100 \mathrm{~g}$ of acetone extract & & \\
\hline \multirow[t]{12}{*}{ Peel } & & 13-octadecanoic acid (6) & $5.59 \%$ & Methanol, oil & $(29,33-35)$ \\
\hline & & Palmitic acid (7) & $30 \%$ & & \\
\hline & & Oleic acid (8) & $7 \%$ & & \\
\hline & & Linoleic acid (9) & $8 \%$ & & \\
\hline & & Methyl palmitate (10) & - & & \\
\hline & & Methyl oleate (11) & - & & \\
\hline & & Methyl linoleate (12) & - & & \\
\hline & & Stearic acid (13) & $2 \%$ & & \\
\hline & & Carvacrol (14) & - & & \\
\hline & & Pentadecanoic acid (15) & $18.81 \%$ of extract & & \\
\hline & & Palmitoleic acid (16) & - & & \\
\hline & & Benzoic acid (17) & $16.04 \%$ of extract & & \\
\hline \multirow[t]{3}{*}{ Leaves } & & Tannic acid (18) & $7.04-12.19 \mathrm{mg} / \mathrm{ml}$ & Ethanol, acetone, petroleum ether & (36) \\
\hline & & Cinnamic acid (19) & $43-80 \mathrm{ng} / \mathrm{g}$ dry weight & Leaf powder & (37) \\
\hline & & Ferulic acid (20) & $2680-5900 \mathrm{ng} / \mathrm{g}$ dry weight & & \\
\hline \multirow[t]{5}{*}{ Bract } & & Delphinidin-3-rutinoside (21) & $0.00-66.70 \mathrm{mg} / 100 \mathrm{~g}$ & Methanol & (38-40) \\
\hline & & Cyanidin-3-rutinoside (22) & $0.00-37.52 \mathrm{mg} / 100 \mathrm{~g}$ & & \\
\hline & & Petunidin-3-rutinoside (23) & $0.00-11.91 \mathrm{mg} / 100 \mathrm{~g}$ & & \\
\hline & & Peonidin-3-rutinoside (24) & $0.00-36.92 \mathrm{mg} / 100 \mathrm{~g}$ & & \\
\hline & & Malvidin-3-rutinoside (25) & $0.00-70.27 \mathrm{mg} / 100 \mathrm{~g}$ & & \\
\hline Seeds & & Leucoanthocyanidin (26) & - & Acetone & (29) \\
\hline Pulp of banana fruit & & Gallic acid (27) & - & Not specified & (41) \\
\hline Over ripe fruit & & Protocatechualdehyde (28) & - & Not specified & (42) \\
\hline \multirow[t]{2}{*}{ Sap } & & Hydroxycinnamic acid (29) & $24-45 \%$ of sap & Ethanol & (43) \\
\hline & & Caffeoylquinic acid $(\mathbf{3 0})$ & $24-45 \%$ of sap & & \\
\hline \multirow[t]{7}{*}{ Ripe fruit } & Flavonoids & Quercetin (31) & $6.5-18.9 \mu \mathrm{g} / 100 \mathrm{~g}$ of dry weight pulp & Pulp & $(41,44)$ \\
\hline & & Proanthocyanidin (32) & - & & \\
\hline & & Catechin (33) & 33.3-143.2 $\mathrm{\mu g} / 100 \mathrm{~g}$ of dry weight pulp & & \\
\hline & & Gallocatechin (34) & 37.3-542 $\mu \mathrm{g} / 100 \mathrm{~g}$ of dry weight pulp & Methanol & $(41,45)$ \\
\hline & & Epicatechin (35) & $17.9-459.8 \mu \mathrm{g} / 100 \mathrm{~g}$ of $\mathrm{dry}$ weight pulp & & \\
\hline & & Procyanidin (36) & 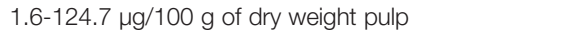 & & \\
\hline & & (+) Catechin hydrate (37) & $23.34 \mathrm{mg} / 100 \mathrm{~g}$ of acetone extract & Acetone & (32) \\
\hline \multirow[t]{3}{*}{ Sap } & & Apigenin (38) & $5.50-23.81 \%$ of sap & Ethanol & (43) \\
\hline & & Myricetin (39) & $1-45 \%$ of sap & & \\
\hline & & Kaempferol (40) & $2.89-23.50 \%$ of sap & & \\
\hline \multirow[t]{6}{*}{ Ripe fruits } & Glycosides & Endo- $\beta$-1,3-glucanase (Ban-Glu) (41) & 208 and 237 amino acids are present in two varieties & Pulp & (46) \\
\hline & & $\alpha$-tocopherol (42) & $2-7 \mathrm{mg} / \mathrm{kg}$ of dry material & Dichloromethane & (31) \\
\hline & Triterpenoids & Cycloartenol (43) & $1-4 \mathrm{mg} / \mathrm{kg}$ of dry material & Dichloromethane & \\
\hline & Sterols & Campesterol (44) & $18-59 \mathrm{mg} / \mathrm{kg}$ of dry material & Dichloromethane & \\
\hline & & Stigmasterol (45) & $23-49 \mathrm{mg} / \mathrm{kg}$ of dry material & & \\
\hline & & $\beta$-sitosterol (46) & $105-226 \mathrm{mg} / \mathrm{kg}$ of dry material & & \\
\hline Peels & & Pyrogallol (47) & $22.24 \%$ & Methanol & (33) \\
\hline Ripe banana & & Sitosteryl glucoside (Sitogluside) (48) & - & Not specified & (47) \\
\hline
\end{tabular}




\begin{tabular}{|c|c|c|c|c|c|}
\hline Plant parts & Category & Phytochemicals from various banana cultivars & Quantitative values & Extract & References \\
\hline Peel & Lignan & Sesamin (49) & - & Methanol, oil & (48) \\
\hline Peel & & Epi-sesamin (50) & - & & \\
\hline \multirow[t]{5}{*}{ Ripe fruit } & Carotenoids & Ascorbic acid (51) & - & Pulp, Peel & (29) \\
\hline & & Retinol (52) & - & & (49) \\
\hline & & $\alpha$-carotene $(\mathbf{5 3})$ & - & & $(50,51)$ \\
\hline & & $\beta$-carotene (54) & - & & \\
\hline & & Zeaxanthin (55) & - & & \\
\hline \multirow[t]{2}{*}{ Unripe fruit } & Miscellaneous & 2-(4-hydroxyphenyl)-naphthalic anhydride (56) & - & Pulp & (52) \\
\hline & & $\begin{array}{l}\text { methyl 2-benzimidazole } \\
\text { carbamate } \mathbf{5 7} \text { ) }\end{array}$ & - & & \\
\hline Peel & & Dopamine (58) & 3.9-381 mg/100 dry weight banana peel extract & Acetone:water & (53) \\
\hline \multirow[t]{7}{*}{ Ripe fruit } & & Serotonin (59) & $1-2 \mathrm{mg} / 100 \mathrm{~g}$ & Not specified & $(54,55)$ \\
\hline & & Histamine (60) & $0.04 \mathrm{mg} / 100 \mathrm{~g}$ & & \\
\hline & & Tryptamine (61) & $0.06 \mathrm{mg} / 100 \mathrm{~g}$ & & \\
\hline & & 2-phenylethylamine (62) & $0.04 \mathrm{mg} / 100 \mathrm{~g}$ & & \\
\hline & & Putrescine (63) & $0.04 \mathrm{mg} / 100 \mathrm{~g}$ & & \\
\hline & & Cadaverine (64) & $0.04 \mathrm{mg} / 100 \mathrm{~g}$ & & \\
\hline & & Tyramine $(65)$ & $0.06 \mathrm{mg} / 100 \mathrm{~g}$ & & \\
\hline \multirow[t]{4}{*}{ Peels } & & 2,3-dihydro-3,5-dihydroxy-6-methyl-4H-pyran-4-one (66) & - & Methanol, oil & $(29,33,48)$ \\
\hline & & 5-(hydroxymethyl)-2- & - & & \\
\hline & & Furancarboxyaldehyde (67) & & & \\
\hline & & cis-9-hexadecenal (68) & $21.20 \%$ & & \\
\hline \multirow[t]{2}{*}{ Rhizome } & & (S)(+)-naproxene (69) & - & & $(56-58)$ \\
\hline & & 2-methoxy-9-phenyl-phenalen-1-one ( $\mathbf{7 0})$ & $0.3 \mathrm{mg} / 478 \mathrm{mg}$ of peel extract & & \\
\hline Rhizome, Root & & Anigorufone (71) & - & Methanol & (29) \\
\hline Fruit & & 2-pentanone (72) & $4.8-6.0 \mathrm{mg} / \mathrm{kg}$ & Not specified & (59) \\
\hline Sap & & $\mathrm{N}$-acetylserotonin $(\mathbf{7 3})$ & $17-34.76 \%$ of sap & Ethanol & (43) \\
\hline
\end{tabular}


such as ferulic acid (62). Boiled plantain pulps with or without peel demonstrated an increased number of phenols in pulps (62). Additionally, protocatechualdehyde, a naturally occurring polyphenol, was isolated, purified, and characterized in green cavendish bananas (42). The phenolic compounds collectively present in the banana are octadeca-9,12,15 trienoic acid (1) (Figure 2), octadeca-9,12-dienoicacid (2), vanillic acid (3), caffeic acid (4), ellagic acid (5), 13-octadecanoic acid (6), palmitic acid (7), oleic acid (8), linoleic acid (9), methyl palmitate (10), methyl oleate (11), methyl linoleate (12), stearic acid (13), carvacrol (14), pentadecanoic acid (15), palmitoleic acid (16), benzoic acid (17), tannic acid (18), cinnamic acid (19), ferulic acid (20), delphinidin-3-rutinoside (21), cyanidin-3rutinoside (22), petunidin-3-rutinoside (23), peonidin-3rutinoside (24), malvidin-3-rutinoside (25) (Figure 3), leucoanthocyanidin (26), gallic acid (27), protocatechualdehyde (28), hydroxycinnamic acid (29), caffeoylquinic acid (30), quercetin (31), proanthocyanidin (32), catechin (33), gallocatechin (34), epicatechin (35), procyanidin (36), (+) catechin hydrate (37), apigenin (38), myricetin (39), kaempferol (40), endo- $\beta$-1,3-glucanase (Ban-Glu) (41), and $\alpha$ tocopherol (42).A triterpenoid, namely cycloartenol (43), was extracted from the dichloromethane extract of ripe pulp of various banana cultivars $(29,31-41,43-46)$.

Banana fruits have substantial phytosterol concentrations (64). Several sterol components are present in the Musa spp., namely, campesterol (44), stigmasterol (45), $\beta$-sitosterol (46) (Figure 4), which exist in the dichloromethane extract (31). The methanol extract of banana peel contains pyrogallol/benzene1,2,3-triol (47) (33). In addition to these phytochemicals, sitosteryl glucoside (sitogluside) (48) is present in ripe banana fruits (47). Two kinds of lignan, namely sesamin (49) and episesamin (50), have also been isolated and identified in the methanol extract of banana peel (48).

Carotenoids, vitamin C (ascorbic acid) (51), and vitamin A (retinol) (52) are the most abundant antioxidants present in the banana pulp and peel (49). Significant quantities of bioactive carotenoids have been extracted and identified in Musa spp. biomasses as well $(50,51)$. Various banana genotypes may even produce higher amounts (approx. 90\%) of vitamin A precursors, such as $\alpha$ - and $\beta$-carotene (53 and 54) (65). Zeaxanthin (55) has additionally been found in bananas. Several additional novel compounds, such as 2-(4-hydroxyphenyl)-naphthalic anhydride (56), and methyl 2-benzimidazolecarbamate (57), were reported to be present in banana (52).

According to Xiao et al. (66), the consumption of banana, which is considered relatively rich in serotonin, leads to a rapid elevation of the hormone level within the blood. The quantity and specific type of biogenic amines formed are affected by the composition of the plant's nutritional intake, microbial flora, storage (e.g., degree of ripeness and temperature), and processing to which they are subjected $(54,67,68)$. The most common amine compounds are spermidine and spermine. Diamines, such as putrescina and agmatina, are precursors of these polyamines (69). Dopamine (58), serotonin (59) and histamine (60) have all been detected in bananas and their by-products (54). Serotonin has been extracted in higher amounts in the fruits of
Musa spp., particularly when compared with other fruits and vegetables (32). Additionally, several biogenic amines, tryptamine (61), 2-phenylethylamine (62), putrescine (63), cadaverine (64), and tyramine (65), are also present in banana (55). Interestingly, a ketone compound, namely 2-pentanone, has been isolated from bananas as well (59). Several other miscellaneous components are reported to exist in Musa spp., including 2,3-dihydro-3,5-dihydroxy-6-methyl-4H-pyran-4-one (66), 5-(hydroxymethyl)-2-furancarboxyaldehyde (67), cis-9hexadecenal (68), (S) (+)-naproxene (69) (Figure 5), 2methoxy-9-phenyl-phenalen-1-one (70), Anigorufone (71), 2pentanone (72), and $\mathrm{N}$-acetylserotonin (73) (33, 43, 48, 56-59). The phytoconstituent compositions of different banana species (Table 1) differ quantitatively due to soil, temperature, banana type, maturation stage, processing site, and other factors (70).

\section{SAFETY PROFILE OF BANANA}

Local and tribal communities have discovered that the use of banana fruit and other parts of the banana plant is non-toxic. Banana fruits and other plant parts are consumed by indigenous populations throughout the world. The banana (M. acuminata) flower is used to prepare a popular Sri Lankan dish as a curry, boiled or deep-fried salad (71). There were no adverse consequences upon the administration of banana (M. acuminata) extracts in preclinical trials $(22,72-74)$. The flowering stalk of $M$. acuminata was documented to be nontoxic against the murine monocytic macrophages cell line (75). A toxicity examination in brine shrimp (administered in Artemia salina) revealed that $M$. acuminata flower extract was safe as well (76). Likewise, the utilization of $M$. acuminata peel as an ingredient in food products suggests that it's considered safe for consumption (77-79). Furthermore, banana peel exhibited no toxicity towards normal human cells (80). According to acute and subacute toxicity analysis, aqueous fermented extract of M. paradisiaca plantain was reported to be non-toxic and considered safe when administered to rats at a dose of $800 \mathrm{mg} /$ $\mathrm{kg}$ body weight, which revealed no significant changes in the hematological and serum biochemical parameters or histopathological studies of the liver and kidney (81). According to Abbas et al. (82), the methanol extract of $M$. paradisiaca (bract and flowering stalk) showed potent nephroprotective activity in gentamicin-induced nephrotoxicity in mice. Cellulose nanofibers isolated from the banana peel ( $M$. paradisiaca) exhibited no cytotoxicity against Caco-2 cell line (83). The methanol extract of $M$. paradisiaca root exhibited no signs of toxicity or mortality in broiler chickens with doses up to $4000 \mathrm{mg} / \mathrm{kg}$ body weight (84). Similarly, the hydro-ethanol extract of pseudostem of $M$. paradisiaca did not demonstrate any signs of toxicity or mortality in male Wistar rats when administered doses of up to $3000 \mathrm{mg} / \mathrm{kg}$ body weight (85). Additionally, the hydro-methanolic extract of M. balbisiana flower exhibited its non-toxic effects in streptozotocin-induced diabetic male albino Wistar rats (86). Aqueous extract of fresh ripe peel (M. sapientum Linn.) also did not induce any cytotoxicity in RAW 264.7 murine macrophage cell lines, which was evident from the presence of $70 \%$ viable cells (87). 


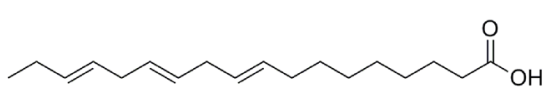

Octadeca-9,12,15 trienoic acid (1)<smiles>CCCCCC=CCC=CCCCCCCCC(=O)O</smiles>

Octadeca-9,12-dienoic acid (2)
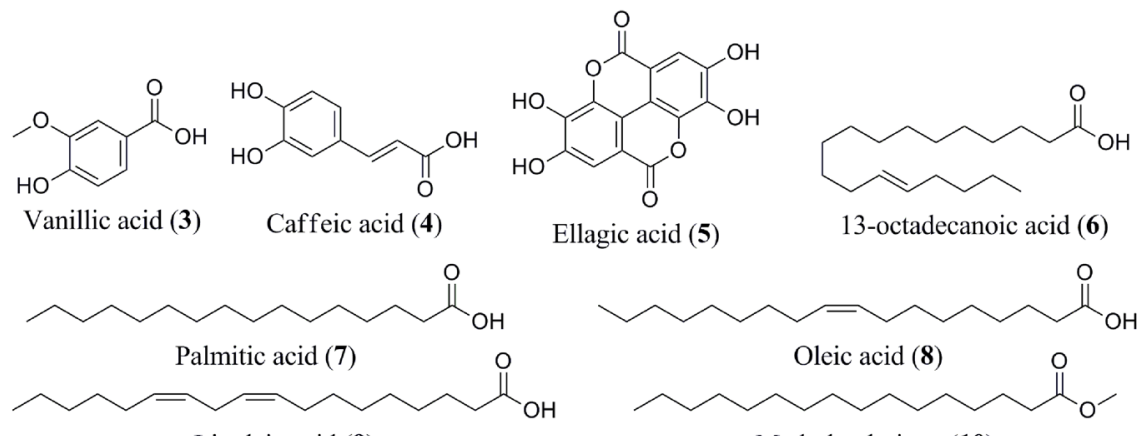

Linoleic acid (9)

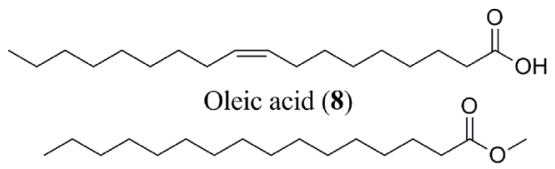

Methyl palmitate (10)

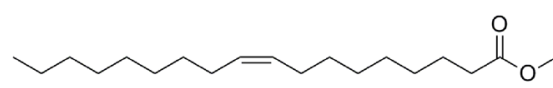

Methyl oleate (11)<smiles>CCCCC/C=C/C/C=C/CCCCCCCC(=O)OC</smiles>

Methyl linoleate (12)<smiles>CCCCCCCCCCCCCCCCCC(=O)O</smiles>

Stearic acid (13)

Carvacrol (14)<smiles>CCCCCCCCCCCCCCC(=O)O</smiles>

Pentadecanoic acid (15)<smiles>CCCCCC/C=C\CCCCCCCC(=O)O</smiles><smiles>O=Cc1cc(O)c(O)c(O)c1</smiles><smiles>CC(=O)OC1OC(COC(=O)c2cc(O)c(O)c(O)c2)C(O)C(OCO)C1O</smiles><smiles>O=C(O)/C=C/c1ccccc1</smiles><smiles>COc1cc(/C=C/C(=O)O)ccc1O</smiles>

Cinnamic acid (19)

Ferulic acid (20)<smiles>CC(C)[C@H](C)OC[C@H]1OC(Oc2cc3c(O)cc(O)cc3[o+]c2-c2cc(O)c(O)c(O)c2)[C@H]([O-])[C@@H](O)[C@H]1O</smiles>

Delphinidin-3-rutinoside (21)<smiles>C=C(O)/C=C/[O+]=C(C)c1ccc(O)c(O)c1</smiles><smiles>O=C(O)c1cc(O)c(O)c(O)c1</smiles><smiles>O</smiles>

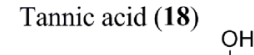<smiles>COc1cc(-c2[o+]c3cc(O)cc(O)c3cc2OC2OC(COC3OC(C)C(O)C(O)C3O)C(O)C(O)C2O)cc(O)c1O</smiles>

Peonidin-3-rutinoside (23)

Petunidin-3-rutinoside (24)

FIGURE 2 | Isolated phytoconstituents (1-24) present in Musa spp.

CANCER PREVENTIVE AND ANTICANCER THERAPEUTIC POTENTIAL OF MUSA SPP.

\section{Literature Search Methodology}

We have followed the guidelines of Preferred Reporting Items for Systemic Reviews and Meta-Analysis (PRISMA) (88) which is a credible process utilized for systematic analysis compilation
(Figure 6). The major databases used to find primary literature were PubMed, ScienceDirect, and Scopus. Additionally, clinical trials were searched using clinicaltrials.gov. There were no time restraints on research articles that were published. The last search was performed in March 2021. Various combinations of keywords that were used included: Musa species; banana; chemopreventive, chemotherapeutic, in vivo, in vitro, cancer, 
<smiles>CC(O)C(O)C(C)COC1OC(C)C(O)C(O)C1O</smiles><smiles></smiles>

Malvidin-3-rutinoside (25)

Hydroxycinnamic acid (29)<smiles>O=C(O)c1cc(O)c(O)c(O)c1</smiles><smiles>O=C(/C=C/c1ccc(O)c(O)c1)OC1(C(=O)O)CC(O)C(O)C(O)C1</smiles>

Caffeoylquinic acid (30)<smiles>O=c1c(O)c(-c2ccc(O)c(O)c2)oc2cc(O)cc(O)c12</smiles>

Quercetin (31)<smiles>Oc1cc(O)c2c(c1)OC(c1cc(O)c(O)c(O)c1)C(O)C2</smiles>

Gallocatechin (34)<smiles>Oc1cc(O)c2c(c1)OC(c1ccc(O)c(O)c1)C(O)C2</smiles>

$(+)$ Catechin hydrate $(37)$<smiles>COc1c(O)cc(C2Oc3c(c(O)cc(O)c3C3c4c(O)cc(O)cc4OC(c4ccc(O)cc4)C3O)CC2O)cc1O</smiles><smiles>Oc1cc(O)c2c(c1)OC(c1ccc(O)c(O)c1)C(O)C2</smiles><smiles>Oc1cc(O)c2c(c1)OC(c1ccc(O)c(O)c1)C(OC1(c3ccc(O)c(O)c3)Oc3cc(O)cc(O)c3C(O)C1O)C2</smiles>

Epicatechin (35)

Procyanidin (36)<smiles>O=c1cc(-c2ccc(O)cc2)oc2cc(O)cc(O)c12</smiles>

Apigenin (38)<smiles>O=c1c(O)c(-c2cc(O)c(O)c(O)c2)oc2cc(O)cc(O)c12</smiles>

Myricetin (39)<smiles>O=c1c(O)c(-c2ccc(O)cc2)oc2cc(O)cc(O)c12</smiles>

Kaempferol (40) Campesterol (44)<smiles>Cc1c(C)c2c(c(C)c1O)CCC(C)(CCCC(C)CCCC(C)C)O2</smiles>

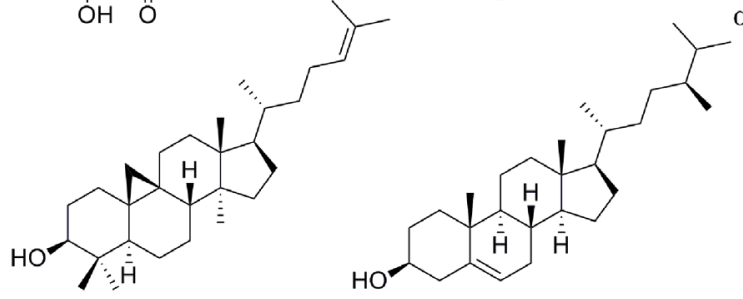

Cycloartenol (43)

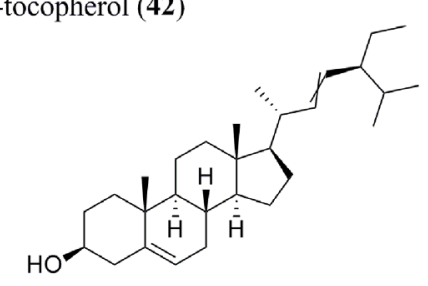

Stigmasterol (45)

FIGURE 3 | Isolated phytoconstituents (25-45) present in Musa spp.

tumor, prevention, treatment, proliferation, apoptosis, and clinical studies. We only considered studies that investigated anticancer effects on banana extracts or constituents against cancer cell lines and/or animal tumor models. Initially, the abstracts of all publications were reviewed to determine the next step, i.e., the collection of full-length articles. Once a full article was reviewed, a decision was made regarding its incorporation for further analysis. Only reports published in 


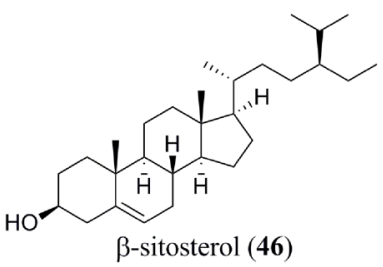<smiles>c1cc2c(cc1C1OC[C@H]3[C@H](c4ccc5c(c4)OCO5)OC[C@H]13)OCO2</smiles>

Sesamin (49)<smiles>Oc1cccc(O)c1O</smiles>

Pyrogallol (47)<smiles>CC[C@H](CC[C@@H](C)[C@H]1CC[C@H]2[C@@H]3CC=C4C[C@@H](O[C@@H]5O[C@H](CO)[C@@H](O)[C@H](O)[C@H]5O)CC[C@]4(C)[C@H]3CC[C@]21C)C(C)C</smiles>

Sitogluside (48)<smiles>O=C1OC([C@H](O)CO)C(O)=C1O</smiles>

Epi-sesamin (50)<smiles>[R]C(C)=CC=CC(C)=CC=CC(C)=CCO</smiles><smiles>CC1=CCCC(C)(C)C1/C=C/C(C)=C/C=C/C(C)=C/C=C/C=C(C)/C=C/C=C(C)/C=C/C1=C(C)CCCC1(C)C</smiles><smiles>CC1=C(/C=C/C(C)=C/C=C/C(C)=C/C=C/C=C(C)/C=C/C=C(C)/C=C/C2=C(C)CCCC2(C)C)C(C)(C)CCC1</smiles>

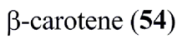<smiles>CCC12CCC(=C(C)CC(O)C1)C(C)=C2C</smiles><smiles>O=C1Oc2ccccc2C1C1C(=O)Oc2ccc(O)cc21</smiles>

2-(4-hydroxyphenyl) naphthalic anhydride (56)<smiles>COC(=O)Nc1nc2ccccc2[nH]1</smiles>

methyl 2-benzimidazole carbamate (57)<smiles>NCCc1c[nH]c2ccccc12</smiles>

$\mathrm{NH}_{2}$<smiles>NCCc1ccccc1</smiles><smiles>NCCc1ccc(O)c(O)c1</smiles>

Dopamine (58)<smiles>NCCc1c[nH]cn1</smiles>

Histamine (60) Tryptamine (61) 2-phenylethylamine (62) Cadaverine (64)<smiles>NCCCCCCCCN</smiles><smiles>NCCc1ccc(O)cc1</smiles>

Tyramine (65)<smiles>CC1=C(O)C(=O)C(O)CO1</smiles>

2,3-dihydro-3,5-dihydroxy6-methyl-4H-pyran-4-one (66)

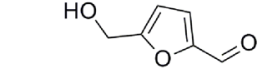

5-(hydroxymethyl)-2furancarboxyaldehyde (67)

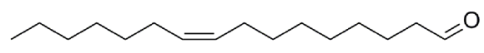

cis-9- hexadecenal (68)

FIGURE 4 | Isolated phytoconstituents (46-68) present in Musa spp.

the English language were included. Reviews, systemic reviews, meta-analyses, letters to editors, book chapters, and conference abstracts were excluded. These searches were also performed by reviewing the bibliography sections of published papers.

\section{Preclinical Studies}

Bananas showed a predominance of flavonoids, cinnamic acids, and polyphenolic compounds, which exhibit chemopreventive potential through various pathways analysed through in vitro
(Table 2) and in vivo (Table 3) studies. Banana, as well their bioactive compounds, which exhibited anticancer, cytotoxic, and antiproliferative activity against various cancer types, are discussed below.

\section{Breast Cancer}

Regarding in vitro studies, aqueous methanol extract of Nendran banana peel exhibited significant antitumor activity against the MCF-7 breast cancer cell line by inducing concentration- 
<smiles>COc1ccc2cc(C(C)C(=O)O)ccc2c1</smiles>

(S) (+)-naproxene (69)<smiles>COC1=Cc2cccc3ccc(-c4ccccc4)c(c23)C1=O</smiles>

2-methoxy-9-phenylphenalen-1-one (70)

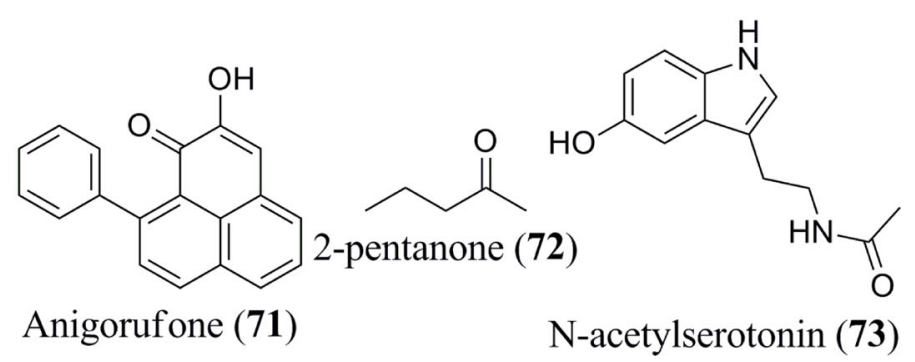

$\mathrm{N}$-acetylserotonin (73)

FIGURE 5 | Isolated phytoconstituents (69-73) present in Musa spp.

dependent apoptosis (89). Another in vitro experimental study showed that the anthocyanin extracted from methanol extracts of $M$. acuminata bract suppressed the proliferation of MCF-7 cells through induction of apoptosis (90). Additionally, $M$. cavendish green peel hydroalcoholic extract exhibited antiproliferative activity against the MCF-7 cell line at a concentration of $100 \mu \mathrm{g} / \mathrm{mL}$ (91). Additionally, hexane extract of banana (M. sapientum) peel and pulp was observed to be cytotoxic and blocked the proliferation of MCF-7 cells (92).

Aqueous fruit extract of ripe banana was utilized for evaluating its anticancer activity in Swiss albino mice bearing Erhlich ascites carcinoma cells. In comparison to the positive control, in which $100 \%$ of the animals died due to the carcinogenic effect, regular feeding of $2 \mathrm{~g}$ banana/day/mouse resulted in the growth suppression of malignant ascites leading to survival of $30 \%$ of the animals with Erhlich carcinoma which survived more than 35 days (104). Mannose-specific M. acuminate lectin (MAL) from the phloem exudates of $M$. acuminate pseudostem also demonstrated antitumor activity in Swiss albino mice bearing Erhlich carcinoma cells. Mechanistic studies showed initiation of apoptosis through the arrest of cell cycle progression at $\mathrm{G} 2 / \mathrm{M}$ phase via stimulation of caspase-3, caspase- 8 and caspase- 9 with increased poly (ADP-ribose) polymerase (PARP) cleavage. It further triggered apoptosis through the phosphoinositide 3-kinase (PI3K)/Akt (also known as protein kinase B) signaling pathway, which inhibited the expression level of phosphorylated Akt (pAkt). MAL also blocked the phosphorylation of extracellular signal-regulated kinase 1 and 2 (ERK1/2) and c-Jun N-terminal kinase (JNK) (94).

\section{Cervical Cancer}

Ethanol extract of banana flower ( $M$. paradisiaca) exhibited anticancer activity against HeLa cervical cancer cell line. The extract inhibited cellular proliferation and induced apoptosis, which was evident by the appearance of breaking up of the nuclei associated with significantly increased caspase- 9 activity. The extract also blocked the cell cycle progression at the $\mathrm{G}_{0} / \mathrm{G}_{1}$ phase as well (93). Interestingly, the extract did not induce any toxicity on normal human peripheral lymphocytes. In a separate study, MAL exhibited similar cytotoxicity and antiproliferative activity against $\mathrm{HeLa}$ cells by initiating apoptosis and arresting cell cycle progression at the $G 2 / \mathrm{M}$ stage through activation of caspase- 3 , caspase- 8 and caspase- 9 associated with elevated PARP cleavage. It also induced apoptosis through the PI3K/Akt signaling pathway, in which it blocked the expression level of phosphorylated Akt (pAkt). It further inhibited the phosphorylation of ERK1/2 and JNK (94). Ferulic acid was isolated from banana peel using Staphylococcus aureus, and it exhibited antiproliferative and cytotoxic activities against HeLa cervical cancer cells by inducing DNA fragmentation (95). Additionally, the methanol extract of $M$. acuminate flower showed antiproliferative and cytotoxic potential against HeLa cells (96). An ethyl acetate fraction of M. $x$ paradisiaca L. leaves also showed strong cytotoxic and anticancer activity against HeLa and A375 cervical cancer cell lines (97).

\section{Colon Cancer}

The hexane fraction of banana (M. sapientum) peel and pulp exhibited in vitro anticancer activity against HCT-116 colon carcinoma cell line. It was observed that the peel and pulp extract arrested cell growth by inducing cytotoxicity and blocked the proliferation of HCT-116 cells (92). In a separate study, $M$. cavendish green peel hydroalcoholic extract suppressed the proliferation of Caco-2 human colorectal adenocarcinoma cells (91). Protocatechualdehyde (PCA, 3,4-dihydroxybenzaldehyde), a polyphenol, was isolated from green cavendish bananas (106). It exhibited antiproliferative activity by triggering apoptosis in human colorectal carcinoma cells (HCT116 and SW480) in a concentration-dependent manner via histone deacetylase 2 (HDAC2)-initiated cyclin D1 suppression. It also downregulated the transcriptional level of the cyclin D1 gene and reduced the expression level of cyclin-dependent kinase 4 (CDK4). Additionally, PCA attenuated the enzymatic activity of HDAC and reduced the expression of HDAC2, but not HDAC1, thereby inducing cell cycle arrest at the $G_{1}$ to $S$ phase in both the cell lines tested (42). PCA increased the expression level of activating transcription factor 3 (ATF3) and ATF3-mediated apoptosis in human colorectal carcinoma (HCT116 and SW480 cell lines). PCA decreased the cell viability in a concentrationdependent manner by increasing the expression of ATF3 protein and mRNA ATF3 levels via phosphorylation of extracellular 


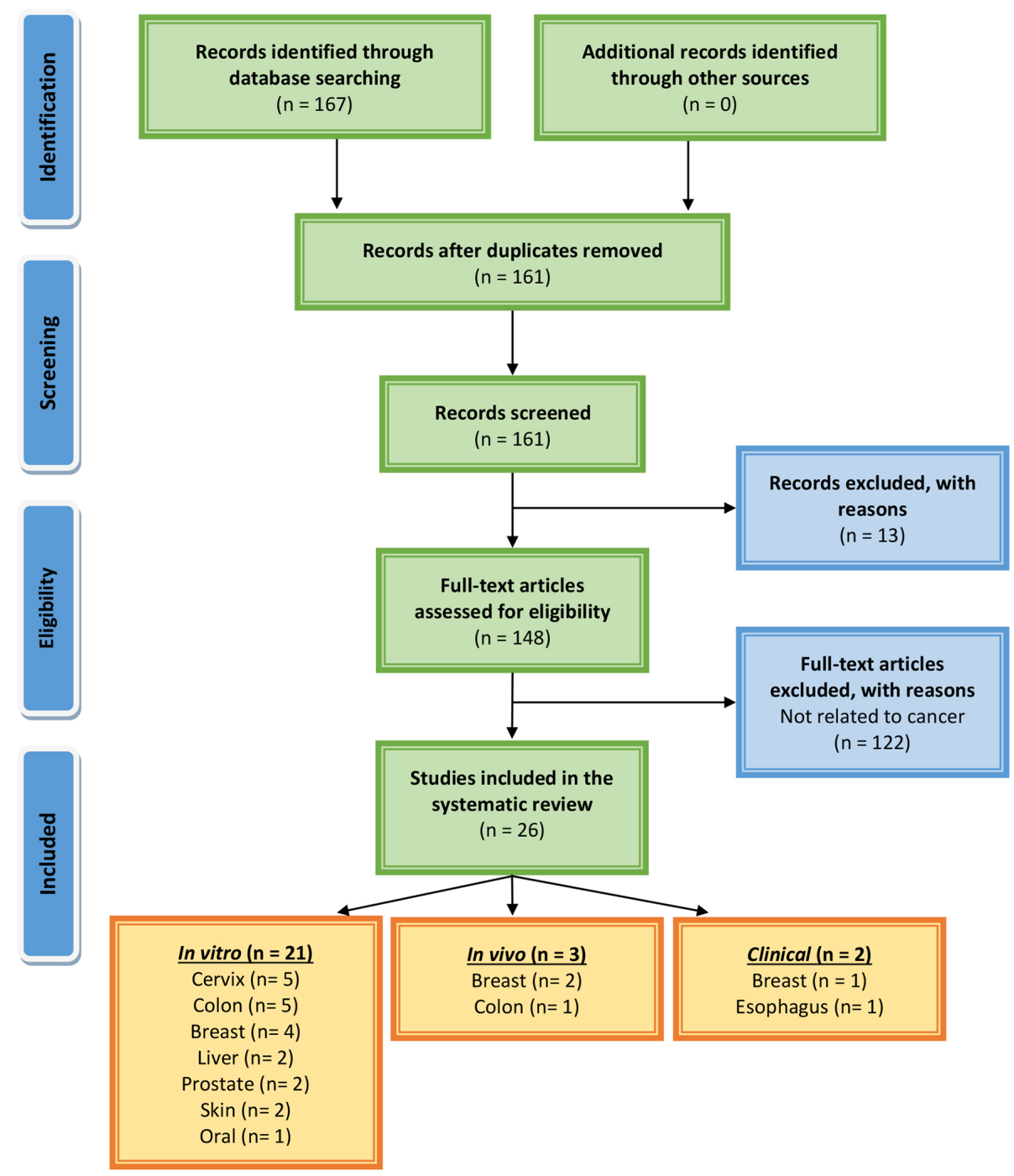

FIGURE 6 | PRISMA flow chart describing the process of literature search and study selection related to banana in cancer research.

signal-regulated protein kinase 1 and $2($ ERK1/2) and p38 mitogen-activated protein kinase (MAPK) proteins and cleavage of PARP (98). Pettersson et al. (59) reported that 2pentanone, a methyl propyl ketone present in banana, exhibited antiproliferative action by inhibiting the prostaglandin $\left(\mathrm{PGE}_{2}\right)$ production and cyclooxygenase-2 (COX-2) protein expression in tumor necrosis factor- $\alpha$ (TNF- $\alpha)$-stimulated colon cancer cells (HT29).

In an in vivo study, green banana flour (10\%) was used as a dietary supplement to evaluate its anticancer potency in 1,2dimethylhydrazine (DMH)-induced colon carcinogenesis in male Swiss mice over a 12 -week experimental period. In all treated groups, it reduced the number of aberrant crypt foci (a colon cancer biomarker) in the colorectal mucosa, suggesting anticarcinogenic efficacy although the detail mechanism of action was not reported (105).

\section{Liver Cancer}

An anticancer study on $M$. cavendish green peel hydroalcoholic extract reported antiproliferative activity against HepG2 human hepatocellular carcinoma cell lines. The extract initiated both apoptosis and necrosis in a concentration-dependant manner, associated with alteration in cell morphology. It was also observed that it decreased the level of mitochondrial membrane potential (MMP) and increased reactive oxygen species (ROS) level (91). Another study has reported that various extracts of banana (Musa AAB var. Nanjanagudu Rasabale) pseudostem and rhizome demonstrated cytotoxicity against HepG2 cell lines. Crude chloroform and acetone extracts of the banana pseudostem and rhizome exhibited substantial cytotoxicity against the cell line tested (99). Bioactive compounds, such as 4-epicyclomusalenone and cycloeucalenol acetate, were isolated from chloroform extract, and chlorogenic 
TABLE 2 | In vitro anticancer activities of Musa sp., extract and its phytoconstituents.

Materials tested Cell line used

Breast cancer

Aqueous methanol extract of Nendran banana peel

MCF-7 breast cancer

Methanol extracts from

Musa acuminata bract

Musa cavendish green peel hydroaloholic extract

Hexane extract of banana (Musa sapientum) peel and pulp

Cervical cancer
Ethanol extract of banana flower

\section{HeLa cells}

HeLa cells

Mannose specific Musa acuminata Lectin (MAL) from the phloem exudates of $M$. acuminata pseudostem

Ferulic acid from banana peel using Staphylococcus aureus HeLa cells

Methanolic flower extract of Musa acuminata

HeLa and A375 cell lines

Colon cancer

Hexane extract of banana (Musa sapientum) peel and pulp

M. cavendish green peel hydroaloholic extract

Protocatechualdehyde

2-pentanone

Liver cancer

Musa cavendish green peel hydroaloholic extract

Crude extracts (BPS and BR) of chloroform and acetone

4-epicyclomusalenone

Cycloeucalenol acetate

Chlorogenic acid

HCT-116

Human colorectal adenocarcinoma Caco-2 cells

HCT116 and SW480

HT29

Hepatocellular carcinoma HepG2 cells

HepG2 cells

HepG2 cells

HepG2 cells

HepG2 cells

Ethyl acetate fraction of ethanol extract of banana soft piths Human oral squamous cell

(BSPs)

Prostate cancer

Aqueous banana flower extrac

carcinoma (OSCC) cell lines (HSC-4)

Epithelial cell line BPH-1 cells

NCaP human prostate cancer cell line

Malignant melanoma A-375 cells B16F10 mouse melanoma cells

Banana peel methanolic extract

Skin cancer

Musa cavendish green peel hydroaloholic extract

Sucrier banana peel methanolic extracts
Musa Paradisiaca L. leaves ethyl extract $\downarrow$ Cell viability; $\uparrow a p o p t o s i s$

IProliferation; $\uparrow$ apoptosis

$\perp$ Proliferation

$\uparrow$ Cytotoxicity; $\perp_{\text {proliferation }}$

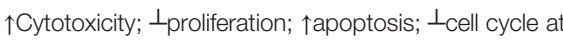
$\mathrm{G}_{0} / \mathrm{G}_{1}$ phase; $\uparrow$ caspase- 9 activity

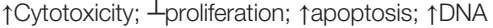

fragmentation; $\perp_{\text {cell }}$ cycle at $\mathrm{G}_{2} / \mathrm{M}$ phase; $\downarrow \mathrm{Bcl}-2$;

$\uparrow$ Bax; activation of caspase- 3 , caspase- 8 and

caspase-9; $\uparrow$ cleaved PARP; $\perp_{\text {pAkt; }} \perp_{\mathrm{p}-\text { ERK } 1 / 2 ;} \perp_{\mathrm{p}}$ JNK

$\downarrow$ Cell viability; $\uparrow$ cytotoxicity; $\uparrow D N A$ fragmentation

$\uparrow$ Cytotoxicity; $\perp_{\text {proliferation }}$

$\uparrow$ Cytotoxicity

$\uparrow$ Cytotoxicity

LProliferation

$\perp$ Proliferation; $\uparrow$ apoptosis; $\downarrow$ (HDAC2)-initiated cyclin D1; $\downarrow$ CDK4; $\downarrow$ enzymatic activity of HDAC; $\downarrow$ HDAC2 cell cycle arrest from $G_{1}$ to $S$ phase; $\uparrow A T F 3 ; \uparrow m R N A$ ATF3; $\uparrow p-E R K 1 / 2 ; \uparrow M A P K ; \uparrow$ PARP cleavage

$\perp \mathrm{PGE}_{2} ; \perp_{\mathrm{COX}-2}$

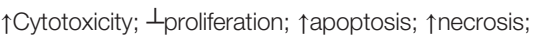
IMMP; $\uparrow$ ROS

$\uparrow$ Cytotoxicity

$\uparrow$ Cytotoxicity

$\uparrow$ Cytotoxicity

$\uparrow$ Cytotoxicity

$\uparrow$ Cytotoxicity

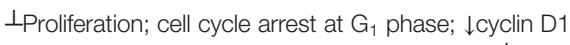
$\downarrow$ cyclin dependent kinase (Cdk) 6; $\uparrow p 53 ; \uparrow p 27 ; \perp$

$\mathrm{PGE}_{2} ; \stackrel{\perp}{ } \mathrm{COX}-2$

$120.6 \mu \mathrm{g} / \mathrm{mL}$

$12.24 \%$ inhibition at $1000 \mu \mathrm{g} / \mathrm{mL}$

$100 \mu \mathrm{g} / \mathrm{mL}$

48.22\% inhibition at $50 \mu \mathrm{g} / \mathrm{mL}$ (peel) and

$61.21 \%$ inhibition at $50 \mu \mathrm{g} / \mathrm{mL}$ (pulp)

$20 \mu \mathrm{g} / \mathrm{mL}$

$13.25 \mu \mathrm{g} / \mathrm{mL}$

$125 \mu \mathrm{g} / \mathrm{mL}$

$71.9 \%$ cytotoxicity at $100 \mu \mathrm{L}$

249.1 and $224.4 \mu \mathrm{g} / \mathrm{mL}$

$62.04 \%$ inhibition at $50 \mu \mathrm{g} / \mathrm{mL}$ (peel) and

$32.76 \%$ inhibition at $50 \mu \mathrm{g} / \mathrm{mL}$ (pulp)

$29.7 \pm 0.007 \%$ inhibition at $1000 \mu \mathrm{g} / \mathrm{mL}$

$71 \%$ inhibition at $200 \mu \mathrm{M}$ and $58 \%$ inhibition at $200 \mu \mathrm{M}$

$43 \%$ reduced cell viability at $200 \mu \mathrm{M}$ and $56 \%$ reduced cell viability at $200 \mu \mathrm{M}$ $400 \mu \mathrm{M}$

$100 \mu \mathrm{g} / \mathrm{mL} ; 100-400 \mu \mathrm{g} / \mathrm{mL}$ (apoptosis); 100,200 and $400 \mu \mathrm{g} / \mathrm{mL}$

$25 \mu \mathrm{g} / \mathrm{mL}$ (chloroform); $300 \mu \mathrm{g} / \mathrm{mL}$ (acetone)

$108 \pm 1.8 \mu \mathrm{g} / \mathrm{mL}$

$93 \pm 1.5 \mu \mathrm{g} / \mathrm{mL}$

$382 \pm 3.6 \mu \mathrm{g} / \mathrm{mL}$

$26.95 \mu \mathrm{g} / \mathrm{mL}$

$2 \mathrm{mg} / \mathrm{mL}$

$25 \mu \mathrm{g} / \mathrm{mL}$

activity

$100 \mu \mathrm{g} / \mathrm{mL}$

$\perp$ Proliferation; $\downarrow \mathrm{MMP}$

$100-500 \mu \mathrm{g} / \mathrm{m}$ 
TABLE 3 | In vivo anticancer activities of Musa spp. extracts.

\begin{tabular}{|c|c|c|c|c|}
\hline Materials tested & Animal models & Effects and mechanisms & Dose & References \\
\hline \multicolumn{5}{|l|}{ Breast cancer } \\
\hline Aqueous extract of ripe banana & $\begin{array}{l}\text { Erhlich's ascites carcinoma cells in Swiss } \\
\text { albino mice }\end{array}$ & $\begin{array}{l}\text { Prolonged survival and reduced tumor } \\
\text { development }\end{array}$ & $\begin{array}{l}2 \mathrm{~g} \text { banana/day/ } \\
\text { mouse }\end{array}$ & $(104)$ \\
\hline $\begin{array}{l}\text { MAL from the phloem exudates of } \\
\text { M. acuminate pseudostem } \\
\text { Colon cancer }\end{array}$ & $\begin{array}{l}\text { Erhlich's ascites carcinoma cells in Swiss } \\
\text { albino mice }\end{array}$ & $\begin{array}{l}\perp \text { Tumor development; } \downarrow \text { neoangiogenesis; } \\
\text { †survival }\end{array}$ & $10 \mathrm{mg} / \mathrm{kg}$ & $(94)$ \\
\hline $\begin{array}{l}\text { Green banana flour (10\%) as } \\
\text { supplement }\end{array}$ & $\begin{array}{l}\text { DMH-induced colon carcinogenesis in male } \\
\text { Swiss mice }\end{array}$ & $\downarrow$ Number of aberrant crypt foci & Not specified & $(105)$ \\
\hline
\end{tabular}

Various symbols $(\uparrow, \downarrow$ and $\perp$ ) indicate increase, decrease and inhibition in the obtained variables, respectively.

acid was extracted and purified from the acetone extract of the banana rhizome. These compounds also exhibited potent cytotoxicity against HepG2 cell lines.

\section{Oral Cancer}

Ethyl acetate sub-fraction of the ethanol extract of banana ( $M$. paradisiaca) soft piths (BSPs) exhibited potent cytotoxic and antiproliferative activity against the human oral squamous cell carcinoma (OSCC) cell line (HSC-4) (100).

\section{Prostate Cancer}

Aqueous banana flower extract exhibited anticancer activity against benign prostatic hyperplasia $(\mathrm{BPH})$ in vitro. The banana flower extract at a concentration of $2 \mathrm{mg} / \mathrm{mL}$ reduced the viability of BPH-1 cells through cell-cycle arrest at the $G_{1}$ phase. Moreover, it reduced the expression level of cyclin D1 and cyclin-dependentkinase6 (Cdk6) and elevated the expression level of p53 and p27 (101). It further reduced $\mathrm{PGE}_{2}$ production by inhibition of COX-2 enzymes during inflammation, which has shown to be the key factor in $\mathrm{BPH}-1$ cell growth and proliferation. In another study, the methanol fraction of the banana peel inhibited testosterone-induced cell growth in a concentration-dependant manner against the androgenresponsive LNCaP human prostate carcinoma cell line by inhibiting $5 \alpha$-reductase activity (102).

\section{Skin Cancer}

M. cavendish green peel hydroalcoholic extract demonstrated antiproliferative and cytotoxic activity against A-375 human malignant melanoma cells at a concentration of $100 \mu \mathrm{g} / \mathrm{mL}$ (91). Another study demonstrated that Sucrier banana peel methanolic extract induced inhibition of melanogenesis in B16F10 mouse melanoma cells by down-regulating microphthalmia-associated transcription factor (MITF) expression and p38 signaling pathway and up-regulating the phosphorylation of $\mathrm{p} 38$, which activated the MITF protein degradation at concentrations of $100-500 \mu \mathrm{g} /$ $\mathrm{mL}$ (103).

\section{Clinical Studies}

According to a hospital-based case-control analysis of Singapore Chinese esophageal cancer patients, esophageal cancer occurs at a higher incidence in male patients who eat fewer or no bananas in their diet and weekly consumption of banana reduces the risk of esophageal cancer (107). Moreover, based on a populationbased case-control study, frequent consumption of bananas (8.9 g/day) lowers the risk of breast cancers (108). Clinical evidence from randomized controlled trials has been lacking. Hence, additional clinical trials are needed to understand the therapeutic effectiveness of banana constituents. Banana is a very acceptable food for all types of communities. So, banana should be a part of regular diet to reduce the incidence of esophageal cancer and breast cancer; however other similar clinical studies should be performed to analyze the therapeutic activity of banana on other cancer types.

\section{CONCLUSION AND FUTURE PERSPECTIVES}

Banana is a magnificent plant that has been cultivated for food and medicinal purposes for thousands of years. We have summarized various secondary metabolites from different banana plant belonging to Musa species in this review. In this article, we analyzed the in vitro and in vivo chemopreventive and chemotherapeutic effects of banana and its phytochemicals and also the toxicity of specific active components. The phytoconstituents were isolated from different varieties of banana belonging to Musa species, such as M. accuminata, M. balbisiana, and other varieties; among which majority of the phytoconstituents belonging to M. accuminata which exhibited chemopreventive and anticancer activities. There are variations in the phytochemical compositions of different varieties of banana due to soil, temperature, banana variety, maturation stage, processing location, and other variables. While the banana fruit (including the pulp and peel) has gained a lot of interest, other parts of the banana plant, such as the leaf, flower, and stem, have also been investigated for anticancer purposes. In addition to banana extracts and fractions, some phytoconstituents, including ferulic acid, protocatechualdehyde, 2-pentanone, 4-epicyclomusalenone, cycloeucalenol acetate, and chlorogenic acid, have been shown to exhibit cancer preventative and anticancer therapeutic abilities. Cancer preventive studies are limited, although two such study is reported where consumption of banana can reduce the incidence of esophageal cancer (107) and breast cancers (108); however other similar studies should be performed to analyze the cancer preventive activity of banana on other cancer types. We have 
also addressed the various mechanisms by which numerous extracts of banana and their active constituents carry out their biological functions in cancer. Bioactive components present in bananas have exhibited momentous cancer preventive and anticancer activities utilizing various mechanisms, which include cytotoxicity, cell cycle arrest, apoptosis of cancer cells, antioxidant, and anti-inflammatory effects. The cell cycle is a sequence of events in a cell that split it into two cells. Cell cycle check points are control mechanisms that ensure the proper progression. Banana and its phytoconstituents induced cell cycle arrest at these check points to halt the progression through the cell cycle of neoplastic cells (Figure 7). Banana phytoconstituents also demonstrate various mechanisms in the modulation of diverse, dysregulated signaling pathways in order to prohibit cancer progression (Figure 8). Banana and its phytochemicals are able to induce changes in expression level of some commonly known genes to regulate well-known signaling networks, such as MAPK signaling pathways, the ERK signaling pathway, the ERK1/2 signaling pathway, and HDAC2 signaling pathway, in addition to inhibiting pro-inflammatory mediators, such as COX-2. By modulating these pathways, phytoconstituents from banana restraint cell proliferation, adhesion, invasion, and angiogenesis in breast, cervical, colorectal, esophageal, hepatic, oral, prostate, and skin cancers (Figure 9).

Poor bioavailability and bioaccessibility of various phytochemical constituents of banana are barriers to their therapeutic use. The weak bioavailability as well as bioaccessibility were due to the initial hepatic first pass effect, poor absorption of the intestines, and low solubility (Sidhu and Zafar, 2018). Different aspects, such as banana processing and variety, often affect bioavailability and accessibility.

Despite the vast amount of research that has been performed and documented over the last few decades, the bulk of the findings cited in this review are focused on in vitro experiments. Breast, cervical, colorectal, esophageal, hepatic, oral, prostate, and skin cancers are only a few of the cancer types affected by banana and its phytochemicals. The reviewed literature reveals the promise that banana and its phytochemicals can be used in chemotherapy for different forms of cancer. The role of banana and its phytoconstituents on breast cancer and colon cancer have been studied extensively in both in vitro and in vivo research. Findings from in vivo studies on other cancer types and clinical situations are sparse. With encouraging preclinical data, mechanistic investigations on anticancer actions of the components of banana are warranted. The translation impact of available research findings is restricted by the lack of welldesigned, prospective clinical studies and safety evaluation of banana extracts and constituents in humans. The potential pharmacokinetic constraints of banana phytochemicals highlight the need to establish efficient and well-regulated delivery mechanisms for optimized delivery systems against various malignancies. More experiments on novel molecular targets and signaling pathways of banana bioactive materials, in addition to well-controlled clinical trials, will increase the therapeutic potential of this popular and medicinal fruit for cancer prevention and treatment. According to the selective toxicity tests, bananas and their main components are safe. However, more research is to be carried out to see whether the same favourable safety profile occurs in human subjects, and to determine which banana secondary metabolites may be cytotoxic, if any. Moreover, banana-derived products may be utilized as an adjuvant to various chemotherapeutic drugs (which have many adverse side effects) for a variety of cancer subtypes.

Our systematic study and review of limitations also identify various future research paths. Although numerous bioactive banana compounds have been identified, further research into the anticancer ability of these phytochemicals found in bananas is required. Furthermore, since the bulk of research is limited to in vitro studies, more in vivo mechanistic experiments should

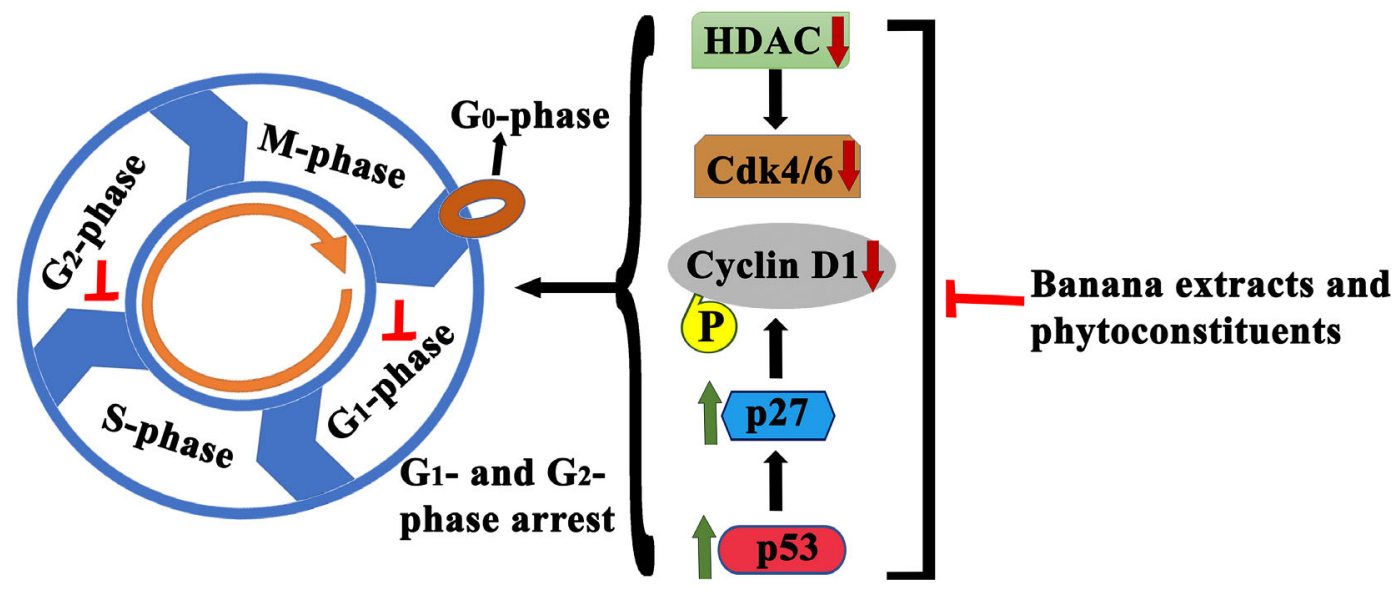

FIGURE 7 | Schematic illustration of anticancer effects of banana extracts and its phytoconstituents through cell cycle arrest. Multiple studies found cell cycle arrest effects of banana extracts and its phytoconstituents at various check points which lead to the proliferation inhibition. 


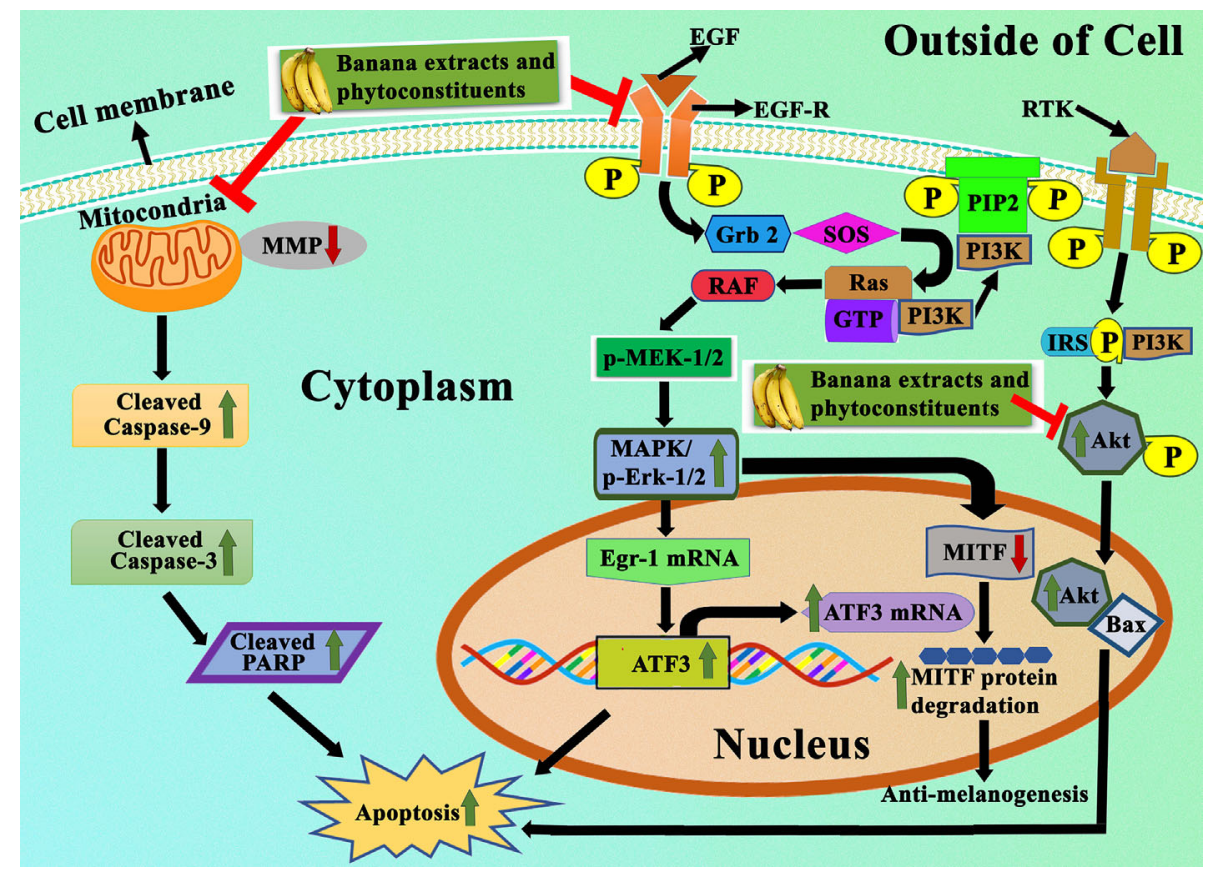

FIGURE 8 Representation of apoptotic effects of banana extracts and its bioactive phytoconstituents. Under the apoptotic effects, banana extracts and its bioactive phytoconstituent can induce the expression of Bax, caspase-3, caspase-9, cleaved PARP and block the expression of Bcl-2. It also regulates the MAPK ERK1/2 signaling pathway, PI3K-Aktsignaling pathway, in which the expressional levels of p-ERK1/2, ATF3, and ATF3 are modulated.

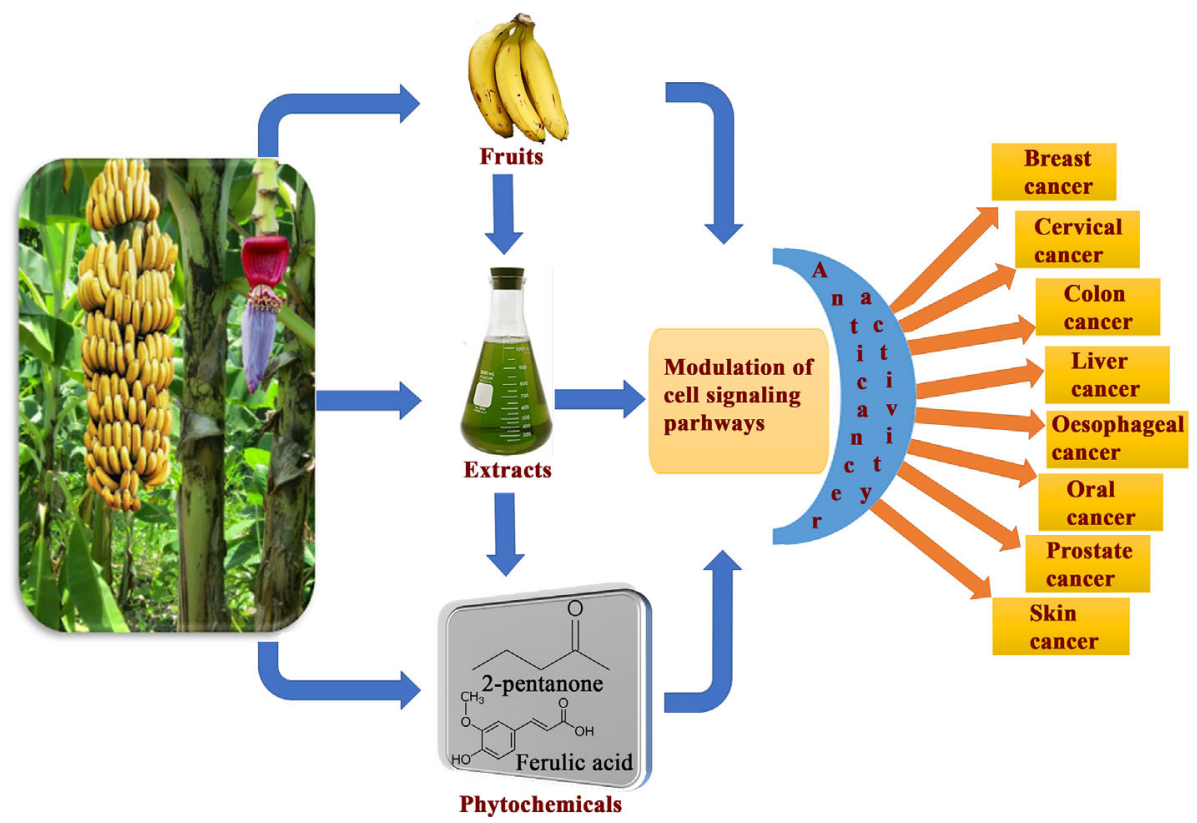

FIGURE 9 | Overview of consumption banana fruits, extracts and its phytoconstituents exhibiting cancer preventive and anticancer activity against various cancer types through modulation of diverse cell signaling pathways. 
be performed. Provided the positive anticancer findings presented in this study, randomized clinical trials involving banana phytochemicals should be carried out. However, further research into the anticancer ability of other important phytochemicals found in bananas is warranted. Characterization of different phytochemicals found in bananas that function alone or synergistically with other compounds or established drugs to have cancer ameliorative or protective effects is also required. In conclusion, based on our in-depth analysis of the existing literature, banana extracts and the isolated phytoconstituents found in banana present as promising medicinal agents for cancer prevention and these agents could also be developed as multi-targeted drugs for cancer pharmacotherapy.

\section{REFERENCES}

1. Gupta SC, Kim JH, Prasad S, Aggarwal BB. Regulation of Survival, Proliferation, Invasion, Angiogenesis, and Metastasis of Tumor Cells Through Modulation of Inflammatory Pathways by Nutraceuticals. Cancer Metastasis Rev (2010) 29(3):405-34. doi: 10.1007/s10555-0109235-2

2. de Mesquita ML, de Paula JE, Pessoa C, de Moraes MO, Costa-Lotufo LV, Grougnet R, et al. Cytotoxic Activity of Brazilian Cerrado Plants Used in Traditional Medicine Against Cancer Cell Lines. J Ethnopharmacol (2009) 123:439-45. doi: 10.1016/j.jep.2009.03.018

3. Mondal A, Bose S, Banerjee S, Patra JK, Malik J, Mandal SK, et al. Marine Cyanobacteria and Microalgae Metabolites-A Rich Source of Potential Anticancer Drugs. Mar Drugs (2020) 18:476. doi: 10.3390/md18090476

4. Clapp RW, Jacobs MM, Loechler EL. Environmental and Occupational Causes of Cancer New Evidence, 2005-2007. Rev Environ Health (2008) 23 (1):1. doi: 10.1515/reveh.2008.23.1.1

5. Bose S, Banerjee S, Mondal A, Chakraborty U, Pumarol J, Croley CR, et al. Targeting the JAK/STAT Signaling Pathway Using Phytocompounds for Cancer Prevention and Therapy. Cells (2020) 9(6):1451. doi: 10.3390/ cells9061451

6. Laget S, Defossez PA. Master and Servant: Epigenetic Deregulations as a Cause and a Consequence of Cancer. Med Sci (Paris) (2008) 24(8-9):725-30. doi: 10.1051/medsci/20082489725

7. Tansaz M, Tajadini H. Comparison of Leiomyoma of Modern Medicine and Traditional Persian Medicine. J Evid Based Complementary Altern Med (2016) 21(2):160-3. doi: 10.1177/2156587215595299

8. Newman DJ, Cragg GM. Natural Products as Sources of New Drugs Over the Nearly Four Decades From 01/1981 to 09/2019. J Nat Prod (2020) 83 (3):770-803. doi: 10.1021/acs.jnatprod.9b01285

9. Bishayee A, Sethi G. Bioactive Natural Products in Cancer Prevention and Therapy: Progress and Promise. Semin Cancer Biol (2016) 40:1-3. doi: 10.1016/j.semcancer.2016.08.006

10. Block KI, Gyllenhaal C, Lowe L, Amedei A, Amin AR, Amin A, et al. Designing a Broad-Spectrum Integrative Approach for Cancer Prevention and Treatment. Semin Cancer Biol (2015) 35:S276-304. doi: 10.1016/ j.semcancer.2015.09.007

11. Kotecha R, Takami A, Espinoza JL. Dietary Phytochemicals and Cancer Chemoprevention: A Review of the Clinical Evidence. Oncotarget (2016) 7 (32):52517. doi: 10.18632/oncotarget.9593

12. Lefranc F, Tabanca N, Kiss R. Assessing the Anticancer Effects Associated With Food Products and/or Nutraceuticals Using In Vitro and In Vivo Preclinical Development-Related Pharmacological Tests. Semin Cancer Biol (2017) 46:14-32. doi: 10.1016/j.semcancer.2017.06.004

13. Karadi RV, Shah A, Parekh P, Azmi P. Antimicrobial Activities of Musa Paradisiaca and Cocos Nucifera. Int J Res Pharm Biomed Sci (2011) 2(1):264-7.

14. Constantine D, Rossel G. The Musaceae. An Annotated List of the Species of Ensete, Musa \& Musella (2001). Available at: http://www.users.globalnet.co. $\mathrm{uk} / \sim \mathrm{drc} /$ musaceae.htm.

\section{DATA AVAILABILITY STATEMENT}

The original contributions presented in the study are included in the article/supplementary material. Further inquiries can be directed to the corresponding authors.

\section{AUTHOR CONTRIBUTIONS}

Conceptualization: AM. Literature search and collection: SBo, $\mathrm{SBa}$, and $\mathrm{PD}$. Writing - original draft preparation: $\mathrm{AM}, \mathrm{SBa}$, and ES. Writing - review and editing: AM, AA, and AB. Supervision: AM. Project administration: AB. All authors contributed to the article and approved the submitted version.

15. Subbaraya U. Farmers Knowledge of Wild Musa in India. Rome: Food and Agriculture Organization of the United States (2006).

16. Ploetz RC, Evans EA. The Future of Global Banana Production. Hortic Rev (2015) 43:311-52. doi: 10.1002/9781119107781.ch06

17. Karamura D, Karamura EB, Guy B. General Plant Morphology of Musa. In: M Pillay and A Tenkouano, editors. Banana Breeding. Boca Raton, FL, USA: CRC Press (2011). p. 1-20. doi: 10.1201/b10514-2

18. Chintamunnee V, Mahomoodally MF. Herbal Medicine Commonly Used Against Non-Communicable Diseases in the Tropical Island of Mauritius. J Herb Med (2012) 2(4):113-25. doi: 10.1016/j.hermed.2012.06.001

19. Ghorbani A, Langenberger G, Liu JX, Wehner S, Sauerborn J. Diversity of Medicinal and Food Plants as Non-Timber Forest Products in Naban River Watershed National Nature Reserve (China): Implications for Livelihood Improvement and Biodiversity Conservation. Econ Bot (2012) 66(2):178-91. doi: 10.1007/s12231-012-9188-1

20. Muthee JK, Gakuya DW, Mbaria JM, Kareru PG, Mulei CM, Njonge FK. Ethnobotanical Study of Anthelmintic and Other Medicinal Plants Traditionally Used in Loitoktok District of Kenya. J Ethnopharmacol (2011) 135(1):15-21. doi: 10.1016/j.jep.2011.02.005

21. De Wet H, Ramulondi M, Ngcobo ZN. The Use of Indigenous Medicine for the Treatment of Hypertension by a Rural Community in Northern Maputaland, South Africa. South Afr J Bot (2016) 103:78-88. doi: 10.1016/ j.sajb.2015.08.011

22. Okon JE, Esenowo GJ, Afaha IP, Umoh NS. Haematopoietic Properties of Ethanolic Fruit Extract of Musa Acuminata on Albino Rats. Bull Env Pharmacol Life Sci (2013) 2:22-6.

23. Di Stasi LC, Oliveira GP, Carvalhaes MA, Queiroz-Junior M, Tien OS, Kakinami SH, et al. Medicinal Plants Popularly Used in the Brazilian Tropical Atlantic Forest. Fitoterapia (2002) 73(1):69-91. doi: 10.1016/ s0367-326x(01)00362-8

24. Camacho-Corona MD, Ramírez-Cabrera MA, Santiago OG, GarzaGonzález E, Palacios ID, Luna-Herrera J. Activity Against Drug ResistantTuberculosis Strains of Plants Used in Mexican Traditional Medicine to Treat Tuberculosis and Other Respiratory Diseases. Phytother Res (2008) 22 (1):82-5. doi: 10.1002/ptr.2269

25. Ticktin T, Dalle SP. Medicinal Plant Use in the Practice of Midwifery in Rural Honduras. J Ethnopharmacol (2005) 96:233-48. doi: 10.1016/ j.jep.2004.09.015

26. Kamatenesi-Mugisha M, Oryem-Origa H. Medicinal Plants Used to Induce Labour During Childbirth in Western Uganda. J Ethnopharmacol (2007) 109 (1):1-9. doi: 10.1016/j.jep.2006.06.011

27. De Wet H, Nzama VN, Van Vuuren SF. Medicinal Plants Used for the Treatment of Sexually Transmitted Infections by Lay People in Northern Maputaland, Kwazulu-Natal Province, South Africa. South Afr J Bot (2012) 78:12-20. doi: 10.1016/j.sajb.2011.04.002

28. Kambizi L, Afolayan AJ. An Ethnobotanical Study of Plants Used for the Treatment of Sexually Transmitted Diseases (Njovhere) in Guruve District, Zimbabwe. J Ethnopharmacol (2001) 77:5-9. doi: 10.1016/s0378-8741(01) 00251-3 
29. Mathew NS, Negi PS. Traditional Uses, Phytochemistry and Pharmacology of Wild Banana (Musa Acuminate Colla): A Review. J Ethnopharmacol (2017) 196:124-40. doi: 10.1016/j.jep.2016.12.009

30. Pereira A, Maraschin M. Banana (Musaspp) From Peel to Pulp: Ethnopharmacology, Source of Bioactive Compounds and Its Relevance for Human Health. J Ethnopharmacol (2015) 160:149-63. doi: 10.1016/ j.jep.2014.11.008

31. Vilela C, Santos SA, Villaverde JJ, Oliveira L, Nunes A, Cordeiro N, et al. Lipophilic Phytochemicals From Banana Fruits of Several Musa Species. Food Chem (2014) 162:247-52. doi: 10.1016/j.foodchem.2014.04.050

32. Islam MR, Afrin S, Khan TA, Howlader ZH. Nutrient Content and Antioxidant Properties of Some Popular Fruits in Bangladesh. Int J Pharm Sci Res (2015) 6:1407-14. doi: 10.13040/IJPSR.0975-8232.6(4).1407-14

33. Niamah AK. Determination, Identification of Bioactive Compounds Extracts From Yellow Banana Peels and Used In Vitro as Antimicrobial. Int J Phytomedicine (2014) 6:625-32.

34. Lu Q, Liu T, Wang N, Dou Z, Wang K, Zuo Y. Nematicidal Effect of Methyl Palmitate and Methyl Stearate Against Meloidogyne Incognita in Bananas. J Agric Food Chem (2020) 68(24):6502-10. doi: 10.1021/acs.jafc.0c00218

35. Budirohmi A, Ahmad A, Taba P, Tahir D. Isolation and Characterization of Starch From the Hump of Kepok Banana (Musa Balbisiana. L) as a Precursor of Biodegradable Polyurethane Synthesis. J Phys Conf Ser (2019) 1341(3):32026. doi: 10.1088/1742-6596/1341/3/032026

36. Meenashree B, Vasanthi VJ, Mary RN. Evaluation of Total Phenolic Content and Antimicrobial Activities Exhibited by the Leaf Extracts of Musa Acuminata (Banana). Int J Curr Microbiol Appl Sci (2014) 3:136-41.

37. Mahouachi J, López-Climent MF, Gómez-Cadenas A. Hormonal and Hydroxycinnamic Acids Profiles in Banana Leaves in Response to Various Periods of Water Stress. Sci World J (2014) 2014:540962. doi: 10.1155/2014/ 540962

38. Gunavathy N, Padmavathy S, Murugavel SC. Phytochemical Evaluation of Musa Acuminata Bract Using Screening, FT-IR and Uv-Vis Spectroscopic Analysis. J Int Acad Res Multidiscip (2014) 2:212-21.

39. Kitdamrongsont K, Pothavorn P, Swangpol S, Wongniam S, Atawongsa K, Svasti J, et al. Anthocyanin Composition of Wild Bananas in Thailand. J Agric Food Chem (2008) 56:10853-7. doi: 10.1021/jf8018529

40. Roobha JJ, Saravanakumar M, Aravindhan KM, Suganyadevi P. In Vitro Evaluation of Anticancer Property of Anthocyanin Extract From Musa Acuminata Bract. Res Pharm (2011) 1:17-21.

41. Bennett RN, Shiga TM, Hassimotto NM, Rosa EA, Lajolo FM, Cordenunsi BR. Phenolics and Antioxidant Properties of Fruit Pulp and Cell Wall Fractions of Postharvest Banana (Musa Acuminata Juss.) Cultivars. J Agric Food Chem (2010) 58(13):7991-8003. doi: 10.1021/jf1008692

42. Jeong JB, Lee SH. Protocatechualdehyde Possesses Anti-Cancer Activity Through Downregulating Cyclin D1 and HDAC2 in Human Colorectal Cancer Cells. Biochem Biophys Res Commun (2013) 430:381-6. doi: 10.1016/ j.bbrc.2012.11.018

43. Pothavorn P, Kitdamrongsont K, Swangpol S, Wongniam S, Atawongsa K, Svasti J, et al. Sap Phytochemical Compositions of Some Bananas in Thailand. J Agric Food Chem (2010) 58:8782-7. doi: 10.1021/jf101220k

44. Gu L, Kelm MA, Hammerstone JF, Beecher G, Holden J, Haytowitz D, et al. Screening of Foods Containing Proanthocyanidins and Their Structural Characterization Using LC-MS/MS and Thiolytic Degradation. J Agric Food Chem (2003) 51:7513-21. doi: 10.1021/jf034815d

45. Swanson MD, Winter HC, Goldstein IJ, Markovitz DM. A Lectin Isolated From Bananas Is a Potent Inhibitor of HIV Replication. J Biol Chem (2010) 285:8646-55. doi: 10.1074/jbc.M109.034926

46. Thulasy G, Nair AS. Comparative Analysis of $\beta$-1,3-glucanase Protein Sequences and Structure in Two Banana Cultivars From Kerala. J Food Biochem (2018) 42:e12559. doi: 10.1111/jfbc.12559

47. Menezes EW, Tadini CC, Tribess TB, Zuleta A, Binaghi J, Pak N, et al. Chemical Composition and Nutritional Value of Unripe Banana Flour (Musa Acuminata Var. Nanicão). Plant Foods Hum Nutr (2011) 66:231-7. doi: 10.1007/s11130-011-0238-0

48. Mordi RC, Fadiaro AE, Owoeye TF, Olanrewaju IO, Uzoamaka GC, Olorunshola SJ. Identification by GC-MS of the Components of Oils of Banana Peels Extract, Phytochemical and Antimicrobial Analyses. Res $J$ Phytochem (2016) 10:39-44. doi: 10.3923/rjphyto.2016.39.44
49. Toh PY, Leong FS, Chang SK, Khoo HE, Yim HS. Optimization of Extraction Parameters on the Antioxidant Properties of Banana Waste. Acta Sci Pol Technol Aliment (2016) 15:65-78. doi: 10.17306/J.AFS.2016.1.7

50. Amorim EP, Cohen KDO, Amorim VBDO, Paes NS, Sousa HN, SantosSerejo JAD, et al. Characterization of Banana Accessions Based on the Concentration of Functional Compounds. Ciec Rural (2011) 41:592-8. doi: 10.1590/S0103-84782011005000042

51. Borges CV, de Oliveira Amorim VB, Ramlov F, da Silva Ledo CA, Donato M, Maraschin M, et al. Characterisation of Metabolic Profile of Banana Genotypes, Aiming at Biofortified Musa Spp. Cultivars. Food Chem (2014) 145:496-504. doi: 10.1016/j.foodchem.2013.08.041

52. Hirai N, Ishida H, Koshimizu K. A Phenalenone-Type Phytoalexin From Musa Acuminata. Phytochemistry (1994) 37:383-5. doi: 10.1016/0031-9422 (94)85064-x

53. Gonzalez-Montelongo R, Lobo MG, Gonzalez M. Antioxidant Activity in Banana Peel Extracts: Testing Extraction Conditions and Related Bioactive Compounds. Food Chem (2010) 119:1030-9. doi: 10.1016/j.foodchem. 2009.08.012

54. Adão RC, Glória MBA. Bioactive Amines and Carbohydrate Changes During Ripening of 'Prata' Banana (Musa Acuminata $\times$ M. Balbisiana). Food Chem (2005) 90:705-11. doi: 10.1016/j.foodchem.2004.05.020

55. Tanasa V, Moise D, Stanca M. Separation and Quantification of Biogenic Amines in Bananas by High Performance Liquid Chromatography. Food Environ Saf J (2015) 14:245-9.

56. Kamo T, Kato N, Hirai N, Tsuda M, Fujioka D, Ohigashi H. Phenylphenalenone-Type Phytoalexins From Unripe Buñgulan Banana Fruit. Biosci Biotechnol Biochem (1998) 62:95-101. doi: 10.1271/ bbb. 62.95

57. Abad T, McNaughton-Smith G, Fletcher WQ, Echeverri F, Diaz-Peñate R, Tabraue C, et al. Isolation of (s)-(+)-Naproxene From Musa Acuminata. Inhibitory Effect of Naproxene and its 7-Methoxy Isomer on Constitutive COX-1 and Inducible COX-2. Planta Med (2000) 66:471-3. doi: 10.1055/s2000-8581

58. Luque-Ortega JR, Martínez S, Saugar JM, Izquierdo LR, Abad T, Luis JG, et al. Fungal-Elicited Metabolites From Plants as an Enriched Source for New Leishmanicidal Agents. Antifungal Phenyl-Phenalenonephytoalexins From the Banana Plant (Musa Acuminata) Target Mitochondria of Leishmania Donovani Promastigotes. Antimicrob Agents Chemother (2004) 48:1534-40. doi: 10.1128/aac.48.5.1534-1540.2004

59. Pettersson J, Karlsson PC, Göransson U, Rafter JJ, Bohlin L. The Flavouring Phytochemical 2-Pentanone Reduces Prostaglandin Production and COX-2 Expression in Colon Cancer Cells. Biol Pharm Bull (2008) 31:534-7. doi: 10.1248/bpb.31.534

60. Borges CV, Maraschin M. Musa Spp.-Functional Properties, Biofortification, and Bioavailability. In: VA Pearson, editor. Bananas: Cultivation, Consumption and Crop Diseases. Hauppauge NY: Nova Science Publishers (2016). p. 1-26.

61. Tsamo CV, Herent MF, Tomekpe K, Emaga TH, Quetin-Leclercq J, Rogez $\mathrm{H}$, et al. Phenolic Profiling in the Pulp and Peel of Nine Plantain Cultivars (Musa Sp.). Food Chem (2015) 167:197-204. doi: 10.1016/j.foodchem. 2014.06.095

62. Tsamo CV, Herent MF, Tomekpe K, Emaga TH, Quetin-Leclercq J, Rogez H, et al. Effect of Boiling on Phenolic Profiles Determined Using HPLC/ESILTQ-Orbitrap-MS, Physico-Chemical Parameters of Six Plantain Banana Cultivars (Musa Sp). J Food Compost Anal (2015) 44:158-69. doi: 10.1016/ j.jfca.2015.08.012

63. Aurore G, Parfait B, Fahrasmane L. Bananas, Raw Materials for Making Processed Food Products. Trends Food Sci Technol (2009) 20:78-91. doi: 10.1016/j.tifs.2008.10.003

64. Sheng Z, Dai H, Pan S, Ai B, Zheng L, Zheng X, et al. Phytosterols in Banana (Musa Spp.) Flower Inhibit $\alpha$-Glucosidase and $\alpha$-Amylasehydrolysations and Glycation Reaction. Int J Food Sci Technol (2017) 52:171-9. doi: $10.1111 /$ ijfs. 13263

65. Lopes S, Borges CV, de Sousa Cardoso SM, de Almeida Pereira da Rocha MF, Maraschin M. Banana (Musa Spp.) as a Source of Bioactive Compounds for Health Promotion. In: Handbook of Banana Production, Postharvest Science, Processing Technology, and Nutrition. Hoboken, NJ, USA: Wiley vol. 31. (2020). p. 227-44. doi: 10.1002/9781119528265.ch12 
66. Xiao R, Beck O, Hjemdahl P. On the Accurate Measurement of Serotonin in Whole Blood. Scand J Clin Lab Invest (1998) 58:505-10. doi: 10.1080/ 00365519850186319

67. Bomtempo LL, Costa AM, Lima H, Engeseth N, Gloria MBA. Bioactive Amines in Passiflora Are Affected by Species and Fruit Development. Food Res Int (2016) 89:733-8. doi: 10.1016/j.foodres.2016.09.028

68. Plonka J, Michalski A. The Influence of Processing Technique on the Catecholamine and Indolamine Contents of Fruits. J Food Compost Anal (2017) 57:102-8. doi: 10.1016/j.jfca.2016.12.023

69. Moinard C, Cynober L, De Bandt JP. Polyamines: Metabolism and Implications in Human Diseases. Clin Nutr (2005) 24:184-97. doi: 10.1016/j.clnu.2004.11.001

70. Falcomer AL, Riquette RFR, de Lima BR, Ginani VC, Zandonadi RP. Health Benefits of Green Banana: A Systematic Review. Nutrients (2019) 11:1222. doi: $10.3390 /$ nu1 1061222

71. Liyanage R, Rizliya V, Jayathilake C, Jayawardana BC, Vidanarachchi JK. (2015). Hypolipidemic Activity and Hypoglycemic Effects of Banana Blossom (Musa Acuminate Colla) Incorporated Experimental Diets in Wistar Rats. In: Sri Lanka Association for the Advancement of Science Proceedings of the 71st Annual Sessions, Part I Section E2 601/E2. Gangodawila, Nugegoda, Sri Lanka: University of Sri Jayewardenepura.

72. Giri SS, Jun JW, Sukumaran V, Park SC. Dietary Administration of Banana (Musa Acuminata) Peel Flour Affects the Growth, Antioxidant Status, Cytokine Responses, and Disease Susceptibility of Rohu, Labeorohita. J Immunol Res (2016) 2016:4086591. doi: 10.1155/2016/4086591

73. Benny $P$, Viswanathan G, Thomas S, Nair A. Investigation of Immunostimulatory Behaviour of Musa Acuminata Peel Extract in Clarias Batrachus. Inst Int Omics Appl Biotech J (2010) 1:39-43.

74. Singhal M, Ratra P. Investigation of Immunomodulatory Potential of Methanolic and Hexane Extract of Musa Acuminata Peel (Plantain) Extracts. Glob J Pharmacol (2013) 7:69-74. doi: 10.5829/idosi.gjp.2013.7.1.71145

75. Lee KH, Padzil AM, Syahida A, Abdullah N, Zuhainis SW, Maziah M, et al. Evaluation of Anti-Inflammatory, Antioxidant and Antinociceptive Activities of Six Malaysian Medicinal Plants. J Med Plants Res (2011) 5:5555-63. doi: 10.5897/JMPR.9000612

76. Sumathy V, Lachumy SJ, Zakaria Z, Sasidharan S. In Vitro Bioactivity and Phytochemical Screening of Musa Acuminata Flower. Pharmacologyonline (2011) 2:118-27.

77. Ling SSC, Chang SK, Sia WCM, Yim HS. Antioxidant Efficacy of Unripe Banana (Musa Acuminate Colla) Peel Extracts in Sunflower Oil During Accelerated Storage. Acta Sci Pol Technol Aliment (2015) 14:343-56. doi: 10.17306/J.AFS.2015.4.34

78. Anal AK, Jaisanti S, Noomhorm A. Enhanced Yield of Phenolic Extracts From Banana Peels (Musa Acuminate Colla AAA) and Cinnamon Barks (Cinnamomum Varum) and Their Antioxidative Potentials in Fish Oil. J Food Sci Technol (2014) 51:2632-9. doi: 10.1007/s13197-012-0793-x

79. Rasidek NAM, Nordin MFM, Shameli K. Formulation and Evaluation of Semisolid Jelly Produced by Musa Acuminate Colla (AAA Group) Peels. Asian Pac J Trop BioMed (2016) 6:55-9. doi: 10.1016/j.apjtb.2015.09.025

80. Lee EH, Yeom HJ, Ha MS, Bae DH. Development of Banana Peel Jelly and its Antioxidant and Textural Properties. Food Sci Biotechnol (2010) 19:449-55. doi: 10.1007/s10068-010-0063-5

81. Ugbogu EA, Ude VC, Elekwa I, Arunsi UO, Uche-Ikonne C, Nwakanma C. Toxicological Profile of the Aqueous-Fermented Extract of Musa Paradisiaca in Rats. Avicenna J Phytomedicine (2018) 8:478-87.

82. Abbas K, Rizwani GH, Zahid H, Qadir MI. Evaluation of Nephroprotective Activity of Musa Paradisiaca L. @ in Gentamicin-Induced Nephrotoxicity. Pak J Pharm Sci (2017) 30:881-90.

83. Tibolla H, Pelissari FM, Martins JT, Lanzoni EM, Vicente AA, Menegalli FC, et al. Banana Starch Nanocomposite With Cellulose Nanofibers Isolated From Banana Peel by Enzymatic Treatment: In Vitro Cytotoxicity Assessment. Carbohydr Polym (2019) 207:169-79. doi: 10.1016/ j.carbpol.2018.11.079

84. Anosa GN, Okoro OJ. Anticoccidial Activity of the Methanolic Extract of Musa Paradisiaca Root in Chickens. Trop Anim Health Prod (2011) 43:2458. doi: 10.1007/s11250-010-9684-1

85. Panigrahi PN, Dey S, Sahoo M, Dan A. Antiurolithiatic and Antioxidant Efficacy of Musa Paradisiaca Pseudostem on Ethylene Glycol-Induced
Nephrolithiasis in Rat. Indian J Pharmacol (2017) 49:77-83. doi: 10.4103/ 0253-7613.201026

86. Ara F, Tripathy A, Ghosh D. Possible Antidiabetic and Antioxidative Activity of Hydro-Methanolic Extract of Musa Balbisiana (Colla) Flower in Streptozotocin-Induced Diabetic Male Albino Wistar Strain Rat: A Genomic Approach. Assay Drug Dev Technol (2019) 17:68-76. doi: 10.1089/adt.2018.889

87. Phuaklee P, Ruangnoo S, Itharat A. Anti-Inflammatory and Antioxidant Activities of Extracts From Musa Sapientum Peel. J Med Assoc Thai (2012) 95(1):S142-6.

88. Liberati A, Altman DG, Tetzlaff J, Mulrow C, Gøtzsche PC, Ioannidis JP, et al. The PRISMA Statement for Reporting Systematic Reviews and MetaAnalyses of Studies That Evaluate Health Care Interventions: Explanation and Elaboration. PloS Med (2009) 6:e1000100. doi: 10.1371/journal. pmed.1000100

89. Durgadevi PKS, Saravanan A, Uma S. Antioxidant Potential and Antitumour Activities of Nendran Banana Peels in Breast Cancer Cell Line. Indian J Pharm Sci (2019) 81:464-73. doi: 10.36468/pharmaceuticalsciences. 531

90. Jenshi Roobha J, Aravindhan MSK. In Vitro Evaluation of Anticancer Property of Anthocyanin Extract From Musa Acuminate Bract. Res Pharm (2011) 1:17-21.

91. Barroso WA, Abreu IC, Ribeiro LS, da Rocha CQ, de Souza HP, de Lima TM. Chemical Composition and Cytotoxic Screening of Musa Cavendish Green Peels Extract: Antiproliferative Activity by Activation of Different Cellular Death Types. Toxicol In Vitro (2019) 59:179-86. doi: 10.1016/j.tiv.2019.04.020

92. Dahham SS, Mohamad TA, Tabana YM, Majid AMSA. Antioxidant Activities and Anticancer Screening of Extracts From Banana Fruit (Musa Sapientum). Acad J Cancer Res (2015) 8:28-34. doi: 10.5829/idosi.ajcr.2015.8.2.95162

93. Nadumane VK, Timsina B. Anti-Cancer Potential of Banana Flower Extract: An In Vitro Study. Bangladesh J Pharmacol (2014) 9:628-35. doi: 10.3329/ bjp.v9i4.20610

94. Srinivas BK, Shivamadhu MC, Jayarama S. Musa Acuminata Lectin Exerts Anti-Cancer Effects on HeLa and EAC Cells Via Activation of Caspase and Inhibitions of Akt, Erk, and Jnk Pathway Expression and Suppresses the Neoangiogenesis In in-Vivo Models. Int J Biol Macromol (2021) 166:117387. doi: 10.1016/j.ijbiomac.2020.10.272

95. Srinivasan S, Valarmathi S, Illanchezian S, Dhanalakshmi KG. Anticancer Activity and DNA Fragmentation of Ferulic Acid From Banana Peel Using HeLa Cell Line. Int J Res Dev Technol (2017) 7:631-5.

96. Das A, Bindhu J, Deepesh P, Priya GS, Soundariya S. In Vitro Anticancer Study of Bioactive Compound Isolated From Musa Extract (Musa Acuminata). Indian J Public Health Res Dev (2020) 11:340-6. doi: 10.37506/v11/i1/2020/ijphrd/193841

97. Deep A, Upadhyay ON, Nandal R, Kumar S, Sharma AK, Wadhwa D. Anticancer Potential of Musa $\times$ Paradisiaca as Cervical Carcinoma and Malignant Melanoma. Res Square (2021) 1-16. doi: 10.21203/rs.2. 20790/v1

98. Lee JR, Lee MH, Eo HJ, Park GH, Song HM, Kim MK, et al. The Contribution of Activating Transcription Factor 3 to Apoptosis of Human Colorectal Cancer Cells by Protocatechualdehyde, A Naturally Occurring Phenolic Compound. Arch Biochem Biophys (2014) 564:203-10. doi: 10.1016/j.abb.2014.10.005

99. Kandasamy S, Ramu S, Aradhya SM. In Vitro Functional Properties of Crude Extracts and Isolated Compounds From Banana Pseudostem and Rhizome. J Sci Food Agric (2016) 96:1347-55. doi: 10.1002/jsfa.7229

100. Ghafar SAA, Fikri IHH, Eshak Z. Antioxidant Activity of Musa Paradisiaca (Banana) Soft Pith and its Cytotoxicity Against Oral Squamous Carcinoma Cell Lines. Malaysian J Sci Health Technol (2019) 3:1-11.

101. Liu LC, Lin YH, Lin YC, Ho CT, Hung CM, Way TD, et al. Banana Flower Extract Suppresses Benign Prostatic Hyperplasia by Regulating the Inflammatory Response and Inducing $\mathrm{G}_{1}$ Cell-Cycle Arrest. In Vivo (2018) 32:1373-9. doi: 10.21873/invivo.11389

102. Akamine K, Koyama T, Yazawa K. Banana Peel Extract Suppressed Prostate Gland Enlargement in Testosterone-Treated Mice. Biosci Biotechnol Biochem (2009) 73:1911-4. doi: 10.1271/bbb.80770

103. Phacharapiyangkul N, Thirapanmethee K, Sa-Ngiamsuntorn K, Panich U, Lee $\mathrm{CH}$, Chomnawang MT. Effect of Sucrier Banana Peel Extracts on 
Inhibition of Melanogenesis Through the ERK Signaling Pathway. Int J Med Sci (2019) 16:602-6. doi: 10.7150/ijms.32137

104. Guha M, Basuray S, Sinha AK. Preventive Effect of Ripe Banana in the Diet on Ehrlich's Ascitic Carcinoma Cell Induced Malignant Ascites in Mice. Nutr Res (2003) 23:1081-8. doi: 10.1016/S0271-5317(03)00090-3

105. Navarro SD, Mauro MO, Pesarini JR, Ogo FM, Oliveira RJ. Resistant Starch: A Functional Food That Prevents DNA Damage and Chemical Carcinogenesis. Genet Mol Res (2015) 14:1679-91. doi: 10.4238/2015. March.6.14

106. Mulvena D, Webb EC, Zerner B. 3, 4-Dihydroxybenzaldehyde a Fungistatic Substance From Green Cavendish Bananas. Phytochemistry (1969) 8:393-5. doi: 10.1016/S0031-9422(00)85436-9

107. De Jong UW, Breslow N, Goh Hong JE, Sridharan M, Shanmugaratnam K. Aetiological Factors in Oesophageal Cancer in Singapore Chinese. Int $J$ Cancer (1974) 13:291-303. doi: 10.1002/ijc.2910130304
108. Malin AS, Qi D, Shu XO, Gao YT, Friedmann JM, Jin F, et al. Intake of Fruits, Vegetables and Selected Micronutrients in Relation to the Risk of Breast Cancer. Int J Cancer (2003) 105:413-8. doi: 10.1002/ijc.11088

Conflict of Interest: The authors declare that the research was conducted in the absence of any commercial or financial relationships that could be construed as a potential conflict of interest.

Copyright $\odot 2021$ Mondal, Banerjee, Bose, Das, Sandberg, Atanasov and Bishayee. This is an open-access article distributed under the terms of the Creative Commons Attribution License (CC BY). The use, distribution or reproduction in other forums is permitted, provided the original author(s) and the copyright owner(s) are credited and that the original publication in this journal is cited, in accordance with accepted academic practice. No use, distribution or reproduction is permitted which does not comply with these terms. 